\title{
6. CHEMISTRY AND ORIGIN OF SECONDARY MINERALS FROM THE DEEP SHEETED DIKES CORED DURING LEG 148 (HOLE 504B) ${ }^{1}$
}

\author{
David A. Vanko, ${ }^{2}$ Christine Laverne, ${ }^{3}$ Paola Tartarotti, ${ }^{4}$ and Jeffrey C. Alt ${ }^{5}$
}

\begin{abstract}
The secondary mineralogy of altered diabase in the lower sheeted dikes cored during Leg 148 comprises an earlier hightemperature assemblage of amphibole, diopside, anorthitic plagioclase, chlorite, titanite, and apatite, overprinted by a subsequent alteration at lower temperatures that led to actinolite, albite, chlorite or chlorite-smectite, talc, epidote, and hydrous calcsilicate (now laumontite). Secondary minerals occur as a pervasive replacement of original igneous minerals; however, they are modally most abundant within irregular patches, centimeter-scale halos of hydrothermal veins, and millimeter-scale veins. The lower sheeted dikes of Leg 148 may have been altered initially within the "reaction zone" of an axial hydrothermal system.

Secondary plagioclase compositions range from anorthite to albite: all are $\mathrm{K}_{2} \mathrm{O}$ poor $(\leq 0.08 \mathrm{wt} \%)$. Secondary calcic plagioclase occurs in association with hydrothermal hornblende as the dominant, high-temperature, early alteration assemblage in the halos of many amphibole veins. In practically every instance, the secondary plagioclase is more calcic than the primary igneous plagioclase. The secondary plagioclase is also clouded with solid and fluid inclusions, contains depressed concentrations of $\mathrm{MgO}$ and $\mathrm{FeO}$, and exhibits bright cathodoluminescence. Hydrothermal amphibole ranging in composition from magnesiohornblende to actinolite occurs as a major vein-forming mineral, as well as a replacement of clinopyroxene in vein halos and in matrix diabase. Secondary clinopyroxene is diopsidic augite, and it forms rare syntaxial rims on igneous augite along the walls of some amphibole veins. The compositions of secondary plagioclase, amphibole, pyroxene, chlorite, chlorite-smectite, talc, and epidote are similar to those reported for the slightly shallower sheeted dike section sampled during Leg 140 at Hole 504B.

Geothermometric evidence suggests that the earliest alteration assemblage of hornblende plus calcic plagioclase represents high temperatures $\left(\geq 400^{\circ} \mathrm{C}\right)$ characteristic of the mid-ocean-ridge reaction zone. Later generations of actinolite + chlorite + albite and epidote + quartz most likely formed at lower temperatures during the waning of axial hydrothermal activity. The presence of calcic plagioclase in the high-temperature alteration assemblage challenges the widely held notion, based upon oftsampled altered basalts, diabases, and spilites, that the dominant plagioclase of the mid-ocean-ridge reaction zone is albite. Evidence from Hole 504B, as well as recent experimental studies, suggests that albite is a later plagioclase in the reaction zone, which formed during waning hydrothermal conditions.
\end{abstract}

\section{INTRODUCTION}

Drill operators have achieved the deepest penetration of any scientific drill hole in the ocean crust at Ocean Drilling Program (ODP) Hole 504B. Located on 5.9-Ma crust about $200 \mathrm{~km}$ south of the Costa Rica Rift in the eastern Pacific, this hole is widely considered to be a reference section through the upper ocean crust (Anderson, Honnorez, et al., 1982; Becker, Sakai, et al., 1989). Studies on Hole 504B are significant for testing models for crustal structure and processes based upon ophiolite studies, theoretical and experimental work, and petrographic studies of samples collected elsewhere from the seafloor.

Drilling at Hole 504B has penetrated $274.5 \mathrm{~m}$ of sediments, a $571.5-\mathrm{m}$ volcanic section, a $209-\mathrm{m}$ transition zone, and $1056 \mathrm{~m}$ into a sheeted dike complex (Fig. 1). Studies of the secondary mineralogy, stable isotopic compositions, and fluid inclusions have led to a model for the hydrothermal history of the upper $1600 \mathrm{~m}$ of the crust at Site

'Alt, J.C., Kinoshita, H., Stokking, L.B., and Michael, P.J. (Eds.), 1996. Proc. $O D P$, Sci. Results, 148: College Station, TX (Ocean Drilling Program).

2Department of Geology, Georgia State University, Atlanta, GA 30303-3083. U.S.A.geodav@gsusgil.gsu.edu

'Laboratoire de Pétrologie Magmatique, URA CNRS 1277, Faculté des Sciences et Techniques de Saint-Jérôme. Avenue Escadrille Normandie-Niemen, 13397 Marseille Cedex 20, France. lacte@vmesal1.u-3mrs.fr

4Dipartimento di Geologia, Paleontologia e Geofisica, Università di Padova, Via Giotto 1,35137 Padova, Italy. tar@epidote.dmp.unipd.it

${ }^{5}$ Department of Geological Sciences, 2534 C.C. Little Building, The University of Michigan, Ann Arbor, MI 48109-1063,U.S.A. jalt@umich.edu
504 (Alt et al., 1985, 1986a, 1986b, 1989a, 1989b; Honnorez et al., 1983; Laverne et al., 1989, 1995). The upper volcanic section underwent low-temperature $\left(<100^{\circ} \mathrm{C}\right)$ oxidizing alteration at high water/ rock ratios $(\approx 100)$, whereas the lower volcanic section was affected by low-temperature alteration under more restricted circulation and more reducing conditions, at lower water/rock ratios $(\approx 10)$. Axial upwelling of hydrothermal fluids along fractures in the underlying, relatively impermeable dikes and mixing with cooler seawater circulating in the more porous and permeable volcanic section led to stockwork-like sulfide mineralization at $900-929 \mathrm{~m}$ below seafloor (mbsf) in the transition zone. There is an abrupt change of alteration characteristics in the underlying transition zone and sheeted dikes, which were altered to minerals characteristic of the greenschist facies at higher temperatures $\left(250^{\circ}-380^{\circ} \mathrm{C}\right)$. Hydrothermal activity resulted in the deposition of a sequence of secondary minerals filling fractures in the upper sheeted dikes: first, amphibole, albite, and chlorite, followed by epidote, quartz, and sulfides. Later recharge of seawater into host rocks led to the precipitation of anhydrite in veins, and finally, off-axis circulation of highly evolved fluids at lower temperatures $\left(<250^{\circ} \mathrm{C}\right)$ resulted in the formation of zeolites in veins and rocks of the upper dike section and zeolites and carbonates in the volcanic section. Trends toward increasing amounts of actinolite, increasing alteration of pyroxene, and decreasing alteration of plagioclase recognized in samples from Leg 111 (1075.5-1287.5 mbsf) suggest generally increasing temperatures of alteration downward in the dikes (Alt et al., 1989b).

The lower sheeted dikes of Leg 148 may have been altered initially within the "reaction zone" of an axial hydrothermal system. At 
Figure 1. Distribution of secondary minerals with depth in Hole 504B (modified from Shipboard Scientific Party, 1993). Lithostratigraphy, seismic stratigraphy, and drilling legs also shown (Anderson,

Honnorez, Becker, et al., 1985; Shipboard Scientific Party, 1988, 1992a, 1992b). ML smect-chl = mixedlayer smectite-chlorite with dominant smectite; ML chl-smect $=$ mixed-layer chlorite-smectite with dominant chlorite; Na-zeolite includes analcime, natrolite, stilbite, and epistilbite; Ca-zeolite includes laumontite, heulandite, and scolecite.

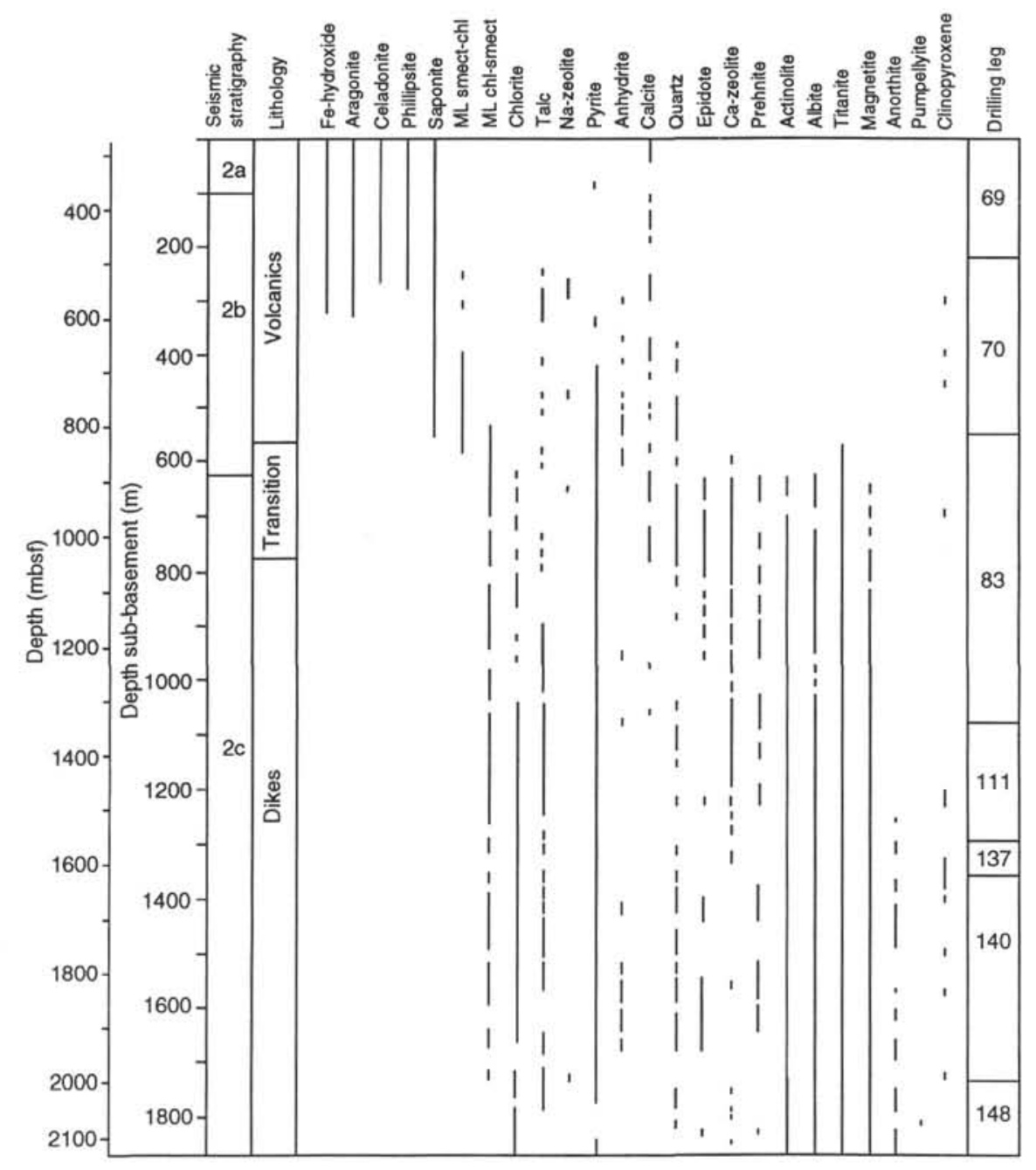

$2111 \mathrm{mbsf}$, Hole 504B is considered to be close to a lithologic boundary separating the sheeted dikes from gabbroic rocks, and this boundary is frequently cited as the location of the reaction zone where axial hydrothermal fluids obtain their final chemical signature before convecting upward and venting at the seafloor. In this paper, the secondary mineralogy of the Hole 504B samples is used in an attempt to describe the mineral assemblage that buffers axial hydrothermal fluids at a depth of about $2 \mathrm{~km}$ below the paleoseafloor. Our results suggest that the axial high-temperature buffering assemblage consists of hornblende (or actinolitic hornblende), diopside, anorthitic plagioclase, chlorite, titanite, and apatite. Subsequent alteration at lower temperatures led to actinolite, albite, chlorite or chlorite-smectite, talc, epidote, and hydrous calc-silicate (now laumontite).

\section{METHODS}

Thin sections from the Leg 148 cores were prepared and mineral chemistry was obtained by electron microprobe (in tables of data, analyses are preceded by a capital letter indicating the place of analysis: $\mathrm{P}=$ Paris, $\mathrm{B}=$ Brest, $\mathrm{V}=$ Padova, Italy, $\mathrm{A}=$ Atlanta, Georgia, and $\mathrm{M}=$ Michigan). All analyses used wavelength-dispersive spectrometers and employed well-characterized natural and synthetic standards. Results were processed into mineral chemical formulas using standardized recalculation schemes. Backscattered electron imaging, energy-dispersive X-ray analysis, and laser Raman microprobe were all used for qualitative mineral identification.
Cathodoluminescence microscopy was carried out in Atlanta using a $30-\mathrm{keV}$ cold-cathode luminoscope. Images obtained in this way served as detailed maps for guiding the placement of the electron beam in subsequent microprobe work.

Core recovery during Leg 148 averaged about $9 \%$. The sampled material may thus be biased toward coherent lithologies. Unsampled lithologies may exist, perhaps representing highly fractured or crumbly rocks. The depth of each recovered sample is constrained to better than $\pm 9 \mathrm{~m}$ by the known depth of the top and bottom of each cored interval and the sample position in the recovered section. Sample depths are assigned with a technique for expanding the recovered rocks throughout the cored interval. In plots involving downhole depth, the symbol sizes usually exceed the depth uncertainty.

\section{PETROGRAPHIC SUMMARY}

Leg 148 samples are petrographically similar to those from the lower sheeted dikes of Legs 137/140 described by Laverne et al. (1995) and Shipboard Scientific Party (1992a, 1992b). Detailed descriptions presented in the Leg 148 Initial Reports (Shipboard Scientific Party, 1993) are summarized below.

\section{Primary Igneous Features}

Fresh, unaltered diabase contains plagioclase + clinopyroxene + titanomagnetite \pm olivine \pm spinel and has a tholeiitic bulk composi- 
tion. Its grain size varies from aphanitic in chilled margins to a typical $1.0-1.5 \mathrm{~mm}$ in the interior of some dikes. Plagioclase and clinopyroxene megacrysts can reach $5 \mathrm{~mm}$ in maximum dimension. There is an overall increase in the maximum grain size with depth, although numerous local variations occur. Some recovered diabases contain sodic plagioclase, quartz, and apatite in interstitial areas, owing to late magmatic in situ crystallization. The diabase has a mid-ocean-ridge basaltic composition with $\mathrm{Mg} *$ (molar $100 \mathrm{Mg} /\left[\mathrm{Mg}+\mathrm{Fe}^{2+}\right]$ ) between 64 and 69 (Shipboard Scientific Party, 1993).

\section{Alteration Features}

Overprinting all diabase samples is a pervasive background alteration, characterized by $10 \%-40 \%$ replacement of primary minerals by secondary phases. Clinopyroxene is replaced by amphibole, and much more rarely by secondary clinopyroxene. Plagioclase may be replaced by one or more generations of secondary plagioclase, anhydrite, laumontite, epidote, chlorite, or some combination of these minerals. Olivine is variably replaced by chlorite, mixed-layer chlorite-smectite, talc, quartz, sulfides, magnetite, and hematite. Titanomagnetite is replaced by titanite.

In addition to pervasive background alteration, many diabase samples contain alteration patches and secondary veins with or without adjacent alteration halos. The centimeter- and decimeter-scale patches are regions of highly altered $(50 \%$ to $80 \%)$ diabase. Patches can be spherical, ovoid, or variably elongated: their irregular and variable shapes appear to be independent of veins or any remaining primary features of the diabase. These patches are apparently zones where hydrothermal solutions had increased access to the diabase that were most likely initiated within zones of original high primary porosity (e.g., gas vesicles, segregation vesicles, or diktytaxitic voids; Helz, 1987).

Hydrothermal veins, on the order of $1 \mathrm{~mm}$ wide, generally consist of amphibole, chlorite, or amphibole + chlorite, all of which may also contain small amounts of apatite and titanite. Less abundant veins include quartz, epidote, and laumontite. Detailed descriptions of veins are given in the Leg 148 Initial Reports (Shipboard Scientific Party, 1993).

Alteration halos adjacent to veins are usually characterized by extensive recrystallization (typically $40 \%-90 \%$ ). The average halo width is $5 \mathrm{~mm}$ flanking actinolite veins and $3 \mathrm{~mm}$ flanking the single 2 -mm-wide quartz vein. Halos can be either simple or compound, the latter commonly consisting of a dark interior zone close to the vein and a lighter outer zone. Primary clinopyroxene in the alteration halos is partly replaced by amphibole, and primary plagioclase is partly replaced by one or more generations of secondary plagioclase (calcic, intermediate, or sodic). Halos also contain accessory secondary titanite, chlorite, and apatite.

Whereas there is a general trend toward increasing extent of alteration and increasing proportion of amphibole with depth in the Hole 504B dike section, the extent of alteration varies considerably through the sheeted dikes. Both hydrothermal veins and alteration patches occur throughout the Leg 148 dike section, showing no apparent depth control.

Unaltered olivine relics are present in some Leg 148 samples, just as some relict olivine survives in several Leg 140 samples. This is in contrast to samples from earlier legs, as there is only one documented occurrence of fresh olivine in the upper dike section (Becker, Sakai, et al., 1988).

\section{MINERALOGY}

New mineral compositional data are presented in this section and are compared to published results from Legs 137/140 (Laverne et al., 1995).

\section{Secondary Plagioclase}

Secondary plagioclase of hydrothermal origin is present in nearly all Leg 148 cores. The amount of secondary plagioclase is small, typically just a few modal percent, with secondary plagioclase chiefly restricted to vein halos and hydrothermal alteration patches (Shipboard Scientific Party, 1993). It commonly occurs as incomplete inclusion-packed rims with a distinct extinction angle relative to the primary plagioclase being replaced and varies in composition from anorthite to albite (Table 1). This wide range in secondary plagioclase compositions is superimposed upon a range in primary plagioclase compositions from anorthite-bytownite through labradoriteandesine.

Commonly, individual thin sections contain calcic megacrysts (typically $>80 \mathrm{~mol} \% \mathrm{An}$ ) and bytownite-labradorite phenocryst cores, with normal zoning to labradorite-andesine. Within vein halos or alteration patches, primary plagioclase is partly replaced by an early generation of hydrothermal calcic plagioclase (as incomplete rims on primary plagioclase laths), which are crosscut by veinlets and contain islands of a later generation of sodic plagioclase (oligoclase and albite).

Ninety-three electron microprobe analyses of plagioclase were completed (Fig. 2). All plagioclases are poor in $\mathrm{K}_{2} \mathrm{O}$, which is $\leq 0.08$ $\mathrm{wt} \%$, and averages $0.011 \mathrm{wt} \%$. Plagioclase commonly contains elevated minor element $(\mathrm{MgO}$ and $\mathrm{FeO})$ concentrations in the primary magmatic phases and markedly reduced concentrations of these same elements in secondary plagioclase (Table 1; Fig. 2). Presumably, the distribution coefficient for $\mathrm{Mg}$ and $\mathrm{Fe}$ varies with temperature, with the more open crystal structure at higher temperature allowing greater minor element substitution.

Secondary calcic plagioclase is most common in extensively altered vein halos, forming as an incomplete replacement around the edges of primary plagioclase laths or a total replacement of smaller laths enclosed in amphibole. Textures are interpreted to indicate that the calcic plagioclase is secondary, and not a primary reverse-zoned magmatic overgrowth. Islands of plagioclase that are completely armored by relict clinopyroxene are notably unaltered. Furthermore, the secondary rims are charged with $10-\mu \mathrm{m}$-scale aqueous fluid inclusions (Kelley et al., 1995; Gu and Vanko, this volume). The presence of fluid and solid inclusions (small spots of more sodic plagioclase) renders the calcic rims heterogeneous on an approximately $5-\mu \mathrm{m}$ scale, which makes microprobe analysis difficult. Any doubt that the rims are plagioclase and not some other calc-silicate phase is dispelled by repeated microprobe totals of nearly $100 \mathrm{wt} \%$ and laser Raman microprobe studies that demonstrate the identical vibrational spectra of both primary plagioclase and secondary rims.

Cathodoluminescence microscopy (Mora and Ramseyer, 1992) was used to image the secondary calcic plagioclase rims, as these luminesce dramatically yellow-green. The resulting images served as maps for directing the placement of the electron microprobe beam. In nearly every case investigated, the secondary plagioclase is more calcic than the replaced plagioclase (Fig. 3), which is similar to the results reported by Laverne et al. (1995). Because the luminescing plagioclase is impoverished in minor elements $\mathrm{Mg}$ and Fe (e.g., Fig. 3 ), it is suggested that one or both of these elements behaves as a cathodoluminescence quencher (Marshall, 1988) in the primary, Mgand $\mathrm{Fe}$-bearing plagioclase.

Plate 1 shows a cathodoluminescence image for a whole thin section. Plate 1, Figure 1, illustrates the remarkable contrast between luminescing plagioclase and the nonluminescent clinopyroxene, amphibole, and chlorite in the thin section. Plagioclase megacrysts that are calcic and contain variable minor element concentrations (Fig. 2) luminesce yellowish. Smaller phenocrysts luminesce yellow to gray, and even bluish where they are zoned to sodic compositions. Careful inspection of photomicrographs reveals abundant apatite (bright orange), albite (reddish orange to blue), as well as calcic pla- 
Table 1. Representative electron microprobe analyses of plagioclase (wt \%), Hole 504B (Leg 148).

\begin{tabular}{|c|c|c|c|c|c|c|c|c|c|c|c|c|}
\hline Core, section: & $24 \mid \mathrm{R}-1$ & $24 \mid \mathrm{R}-1$ & $241 \mathrm{R}-1$ & $24 I R-1$ & $242 \mathrm{R}-1$ & $242 \mathrm{R}-1$ & $246 \mathrm{R}-1$ & $246 \mathrm{R}-1$ & $246 \mathrm{R}-1$ & $246 \mathrm{R}-1$ & $246 \mathrm{R}-1$ & $246 \mathrm{R}-1$ \\
\hline $\begin{array}{l}\text { Interval }(\mathrm{cm}) \text { : } \\
\text { Piece no.: }\end{array}$ & 91-95 & $91-95$ & Piece 15 & Piece 15 & Piece 9 & Piece 9 & & & & & & \\
\hline Analysis no.: & P2003 & P2010 & A 35 & A37 & A18 & A21 & A4 & A5 & A7 & A8 & A9 & $\mathrm{A} 12$ \\
\hline Type: & $\begin{array}{c}\text { Primary } \\
\text { magmatic }\end{array}$ & Rim & $\begin{array}{c}\text { Primary } \\
\text { magmatic }\end{array}$ & $\begin{array}{l}\text { Cathodo- } \\
\text { luminescent }\end{array}$ & $\begin{array}{c}\text { Primary } \\
\text { magmatic }\end{array}$ & $\begin{array}{l}\text { Cathodo- } \\
\text { luminescent }\end{array}$ & $\begin{array}{c}\text { Mega- } \\
\text { phenocryst }\end{array}$ & $\begin{array}{c}\text { Primary } \\
\text { magmatic }\end{array}$ & $\begin{array}{l}\text { Cathodo- } \\
\text { luminescent }\end{array}$ & $\begin{array}{c}\text { Sodic } \\
\text { vein }\end{array}$ & $\begin{array}{c}\text { Primary } \\
\text { magmatic }\end{array}$ & $\begin{array}{l}\text { Cathodo- } \\
\text { luminescent }\end{array}$ \\
\hline \multicolumn{13}{|l|}{ Oxides: } \\
\hline $\mathrm{SiO}_{2}$ & $\begin{array}{r}46.28 \\
0.00\end{array}$ & 62.95 & $\begin{array}{r}56.79 \\
0.03\end{array}$ & $\begin{array}{r}49.36 \\
0.00\end{array}$ & $\begin{array}{r}51.89 \\
0.05\end{array}$ & 49.50 & 47.18 & 50.25 & 47.26 & 58.67 & 51.05 & 47.28 \\
\hline $\begin{array}{l}\mathrm{TiO}_{2} \\
\mathrm{Al}_{2} \mathrm{O}_{3}\end{array}$ & $\begin{array}{r}0.02 \\
32.91\end{array}$ & $\begin{array}{r}0.00 \\
21.84\end{array}$ & $\begin{array}{r}0.03 \\
27.52\end{array}$ & $\begin{array}{r}0.00 \\
33.30\end{array}$ & $\begin{array}{r}0.05 \\
29.93\end{array}$ & $\begin{array}{r}0.00 \\
32.17\end{array}$ & $\begin{array}{r}0.01 \\
33.67\end{array}$ & $\begin{array}{r}0.04 \\
30.72\end{array}$ & $\begin{array}{r}0.01 \\
34.07\end{array}$ & $\begin{array}{r}0.00 \\
266.71\end{array}$ & $\begin{array}{r}0.04 \\
30.75\end{array}$ & $\begin{array}{r}0.01 \\
33.54\end{array}$ \\
\hline $\mathrm{FeO}^{\mathrm{A}_{2}}$ & $\begin{array}{r}32.91 \\
0.46\end{array}$ & $\begin{array}{r}12.84 \\
0.06\end{array}$ & $\begin{array}{r}2.52 \\
0.58\end{array}$ & 0.44 & $\begin{array}{r}2.93 \\
0.85\end{array}$ & 0.20 & $\begin{array}{r}3.3 .07 \\
0.36\end{array}$ & 0.63 & $\begin{array}{r}3.017 \\
0.21\end{array}$ & $\begin{array}{r}20.71 \\
0.04\end{array}$ & 0.59 & $\begin{array}{r}3.34 \\
0.15\end{array}$ \\
\hline $\mathrm{MnO}$ & 0.00 & 0.01 & 0.05 & 0.00 & 0.00 & 0.00 & 0.02 & 0.00 & 0.02 & 0.00 & 0.01 & 0.00 \\
\hline $\mathrm{MgO}$ & 0.23 & 0.01 & 0.05 & 0.00 & 0.19 & 0.00 & 0.20 & 0.25 & 0.00 & 0.00 & 0.25 & 0.00 \\
\hline $\mathrm{CaO}$ & 17.05 & 3.01 & 9.80 & 14.67 & 13.10 & 14.72 & 16.95 & 14.12 & 15.50 & 8.01 & 14.24 & 16.23 \\
\hline $\mathrm{Na}_{2} \mathrm{O}$ & 1.82 & 10.21 & 6.45 & 3.13 & 4.06 & 3.06 & 1.53 & 3.29 & 2.29 & 7.19 & 3.41 & 1.92 \\
\hline $\mathrm{K}_{2} \mathrm{O}$ & 0.00 & 0.04 & 0.00 & 0.00 & 0.00 & 0.00 & 0.00 & 0.01 & 0.02 & 0.01 & 0.01 & 0.00 \\
\hline Total & 98.77 & 98.13 & 101.27 & 100.90 & 100.07 & 99.65 & 99.92 & 99.31 & 99.38 & 100.63 & 100.35 & 99.13 \\
\hline An & 83.8 & 14.0 & 45.6 & 72.1 & 64.1 & 72.7 & 86.0 & 70.3 & 78.8 & 38.1 & 69.7 & 82.4 \\
\hline $\mathrm{Ab}$ & 16.2 & 85.8 & 54.4 & 27.9 & 35.9 & 27.3 & 14.0 & 29.6 & 21.1 & 61.9 & 30.2 & 17.6 \\
\hline Or & 0.0 & 0.2 & 0.0 & 0.0 & 0.0 & 0.0 & 0.0 & 0.1 & 0.1 & 0.1 & 0.1 & 0.0 \\
\hline \multicolumn{13}{|l|}{ Cations: } \\
\hline $\mathrm{Si}$ & 2.158 & 2.833 & 2.529 & 2.234 & 2.362 & 2.266 & 2.167 & 2.309 & 2.175 & 2.605 & 2.321 & 2.183 \\
\hline $\mathrm{Ti}$ & 0.001 & 0.000 & 0.001 & 0.000 & 0.002 & 0.000 & 0.000 & 0.001 & 0.000 & 0.000 & 0.001 & 0.000 \\
\hline Al & 1.809 & 1.159 & 1.445 & 1.777 & 1.606 & 1.736 & 1.823 & 1.664 & 1.849 & 1.398 & 1.648 & 1.826 \\
\hline $\mathrm{Fe}$ & 0.018 & 0.002 & 0.022 & 0.017 & 0.032 & 0.008 & 0.014 & 0.024 & 0.008 & 0.001 & 0.022 & 0.006 \\
\hline Mn & 0.000 & 0.000 & 0.002 & 0.000 & 0.000 & 0.000 & 0.001 & 0.000 & 0.001 & 0.000 & 0.000 & 0.000 \\
\hline $\mathrm{Mg}$ & 0.016 & 0.001 & 0.003 & 0.000 & 0.013 & 0.000 & 0.014 & 0.017 & 0.000 & 0.000 & 0.017 & 0.000 \\
\hline $\mathrm{Ca}$ & 0.852 & 0.145 & 0.468 & 0.712 & 0.639 & 0.722 & 0.834 & 0.695 & 0.764 & 0.381 & 0.694 & 0.803 \\
\hline $\mathrm{Na}$ & 0.165 & 0.891 & 0.557 & 0.275 & 0.358 & 0.272 & 0.136 & 0.293 & 0.204 & 0.619 & 0.301 & 0.172 \\
\hline $\mathrm{K}$ & 0.000 & 0.002 & 0.000 & 0.000 & 0.000 & 0.000 & 0.000 & 0.001 & 0.001 & 0.001 & 0.001 & 0.000 \\
\hline Sum & 5.019 & 5.034 & 5.026 & 5.014 & 5.012 & 5.002 & 4.989 & 5.005 & 5.003 & 5.006 & 5.005 & 4.990 \\
\hline
\end{tabular}

Note: $\mathrm{FeO}^{*}$ indicates all $\mathrm{Fe}$ calculated as $\mathrm{FeO}$. 
Table 1 (continued).

\begin{tabular}{|c|c|c|c|c|c|c|c|c|c|c|c|c|c|c|c|}
\hline Core, section: & $247 \mathrm{R}-1$ & $247 \mathrm{R}-1$ & $252 \mathrm{R}-1$ & $252 \mathrm{R}-1$ & $252 \mathrm{R}-1$ & $252 \mathrm{R}-1$ & $252 \mathrm{R}-1$ & $252 \mathrm{R}-1$ & $252 \mathrm{R}-1$ & $252 \mathrm{R}-1$ & $247 \mathrm{R}-1$ & $247 \mathrm{R}-1$ & $250 \mathrm{R}-1$ & $250 \mathrm{R}-1$ & $250 \mathrm{R}-1$ \\
\hline Interval $(\mathrm{cm})$ : & $14-18$ & 14-18 & $0-4$ & $0-4$ & $0-4$ & $29-33$ & 29-33 & $15-20$ & $15-20$ & $15-20$ & $36-43$ & $36-43$ & & & \\
\hline Piece no.: & & & & & & & & & & & & & Piece 2 & Piece 2 & Piece 2 \\
\hline Analysis no.: & P2019 & P2021 & P2024 & P2025 & P2035 & B7019 & B7020 & M82 & M83 & M85 & P2075 & P2077 & A28 & A34 & A47 \\
\hline Type: & $\begin{array}{c}\text { Primary } \\
\text { magmatic }\end{array}$ & Rim & Rim & Rim & $\begin{array}{c}\text { Primary } \\
\text { magmatic }\end{array}$ & $\begin{array}{c}\text { Primary } \\
\text { magmatic }\end{array}$ & $\operatorname{Rim}$ & Patch & Patch & Patch & $\begin{array}{c}\text { Primary } \\
\text { magmatic }\end{array}$ & Rim & $\begin{array}{c}\text { Primary } \\
\text { magmatic }\end{array}$ & $\begin{array}{c}\text { Cathodo- } \\
\text { luminescent }\end{array}$ & $\begin{array}{l}\text { Albite } \\
\text { replacement }\end{array}$ \\
\hline \multicolumn{16}{|l|}{ Oxides: } \\
\hline $\mathrm{SiO}_{2}$ & 47.74 & 45.21 & 63.10 & 45.52 & 52.29 & 48.98 & 47.01 & 50.24 & 44.11 & 64.47 & 49.28 & 46.22 & 53.08 & 48.83 & 65.20 \\
\hline $\mathrm{TiO}_{2}^{2}$ & 0.03 & 0.00 & 0.06 & 0.06 & 0.03 & 0.04 & 0.00 & 0.09 & 0.03 & 0.05 & 0.00 & 0.01 & 0.01 & 0.00 & 0.02 \\
\hline $\mathrm{Al}_{2} \mathrm{O}_{3}$ & 30.15 & 32.45 & 23.60 & 34.57 & 29.33 & 31.19 & 33.36 & 29.26 & 33.84 & 20.88 & 31.05 & 33.74 & 29.34 & 33.61 & 22.63 \\
\hline $\mathrm{FeO}^{*}$ & 0.58 & 0.27 & 0.04 & 0.17 & 0.61 & 0.33 & 0.02 & 0.73 & 0.17 & 0.00 & 0.54 & 0.15 & 0.80 & 0.32 & 0.07 \\
\hline $\mathrm{MnO}$ & 0.02 & 0.06 & 0.00 & 0.01 & 0.10 & 0.00 & 0.00 & 0.01 & 0.00 & 0.00 & 0.00 & 0.10 & 0.00 & 0.04 & 0.00 \\
\hline $\mathrm{MgO}$ & 0.32 & 0.05 & 0.02 & 0.01 & 0.21 & 0.28 & 0.00 & 0.20 & 0.00 & 0.00 & 0.26 & 0.00 & 0.15 & 0.00 & 0.00 \\
\hline $\mathrm{CaO}$ & 14.94 & 16.46 & 4.93 & 17.66 & 13.24 & 15.98 & 16.91 & 13.63 & 18.08 & 2.37 & 14.63 & 16.77 & 12.32 & 14.90 & 3.26 \\
\hline $\mathrm{Na}_{2} \mathrm{O}$ & 2.96 & 1.94 & 9.11 & 1.42 & 3.95 & 2.28 & 1.58 & 3.86 & 1.48 & 10.89 & 3.00 & 2.13 & 4.63 & 2.79 & 10.82 \\
\hline $\mathrm{K}_{2} \mathrm{O}$ & 0.00 & 0.08 & 0.00 & 0.00 & 0.00 & 0.00 & 0.00 & 0.00 & 0.01 & 0.04 & 0.00 & 0.01 & 0.01 & 0.00 & 0.00 \\
\hline Total & 96.74 & 96.52 & 100.86 & 99.42 & 99.76 & 99.08 & 98.88 & 98.02 & 97.72 & 98.70 & 98.76 & 99.13 & 100.34 & 100.49 & 102.00 \\
\hline An & 73.6 & 82.0 & 23.0 & 87.3 & 64.9 & 79.5 & 85.5 & 66.1 & 87.0 & 10.7 & 72.9 & 81.3 & 59.5 & 74.7 & 14.3 \\
\hline $\mathrm{Ab}$ & 26.4 & 17.5 & 77.0 & 12.7 & 35.1 & 20.5 & 14.5 & 33.9 & 12.9 & 89.1 & 27.1 & 18.7 & 40.5 & 25.3 & 85.7 \\
\hline Or & 0.0 & 0.5 & 0.0 & 0.0 & 0.0 & 0.0 & 0.0 & 0.0 & 0.1 & 0.2 & 0.0 & 0.1 & 0.1 & 0.0 & 0.0 \\
\hline \multicolumn{16}{|l|}{ Cations: } \\
\hline $\mathrm{Si}$ & 2.264 & 2.156 & 2.771 & 2.108 & 2.385 & 2.262 & 2.178 & 2.342 & 2.087 & 2.880 & 2.280 & 2.145 & 2.404 & 2.219 & 2.827 \\
\hline $\mathrm{Ti}$ & 0.001 & 0.000 & 0.002 & 0.002 & 0.001 & 0.001 & 0.000 & 0.003 & 0.001 & 0.002 & 0.000 & 0.000 & 0.000 & 0.000 & 0.001 \\
\hline $\mathrm{Al}$ & 1.686 & 1.825 & 1.222 & 1.888 & 1.577 & 1.698 & 1.822 & 1.608 & 1.888 & 1.100 & 1.694 & 1.846 & 1.566 & 1.800 & 1.157 \\
\hline $\mathrm{Fe}$ & 0.023 & 0.011 & 0.001 & 0.007 & 0.023 & 0.013 & 0.001 & 0.028 & 0.007 & 0.000 & 0.021 & 0.006 & 0.030 & 0.012 & 0.003 \\
\hline $\mathrm{Mn}$ & 0.001 & 0.002 & 0.000 & 0.000 & 0.004 & 0.000 & 0.000 & 0.000 & 0.000 & 0.000 & 0.000 & 0.004 & 0.000 & 0.002 & 0.000 \\
\hline $\mathrm{Mg}$ & 0.023 & 0.004 & 0.001 & 0.001 & 0.014 & 0.019 & 0.000 & 0.014 & 0.000 & 0.000 & 0.018 & 0.000 & 0.010 & 0.000 & 0.000 \\
\hline $\mathrm{Ca}$ & 0.759 & 0.841 & 0.232 & 0.876 & 0.647 & 0.791 & 0.839 & 0.681 & 0.917 & 0.113 & 0.725 & 0.834 & 0.598 & 0.725 & 0.151 \\
\hline $\mathrm{Na}$ & 0.272 & 0.179 & 0.776 & 0.128 & 0.349 & 0.204 & 0.142 & 0.349 & 0.136 & 0.943 & 0.269 & 0.192 & 0.407 & 0.246 & 0.910 \\
\hline $\mathrm{K}$ & 0.000 & 0.005 & 0.000 & 0.000 & 0.000 & 0.000 & 0.000 & 0.000 & 0.001 & 0.002 & 0.000 & 0.001 & 0.001 & 0.000 & 0.000 \\
\hline Sum & 5.028 & 5.023 & 5.004 & 5.010 & 5.000 & 4.989 & 4.982 & 5.025 & 5.036 & 5.041 & 5.007 & 5.028 & 5.016 & 5.004 & 5.049 \\
\hline
\end{tabular}



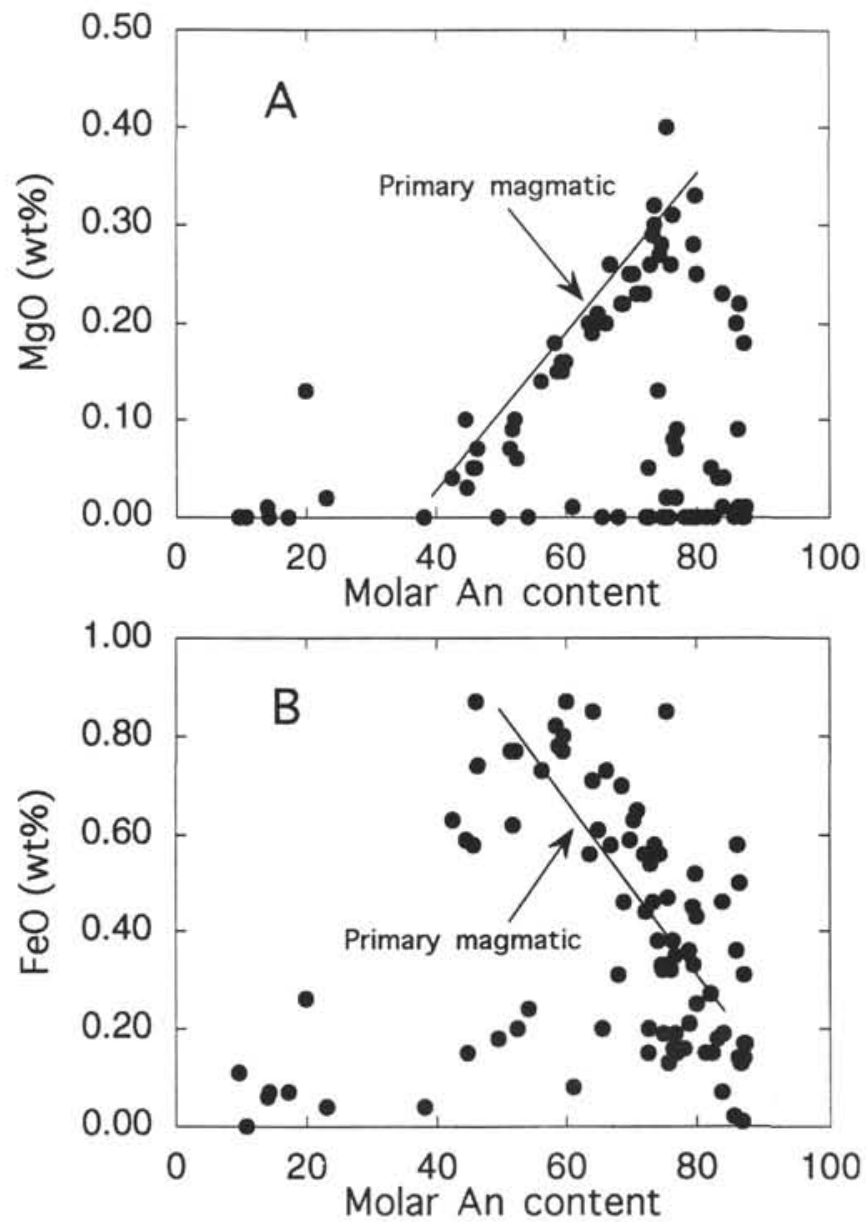

Figure 2. Plots of molar An content vs. weight percentage of selected minor elements, determined by electron microprobe. $\mathrm{A}$. $\mathrm{MgO}$ vs. An content. Note that calcic plagioclases generally fall into either a high-MgO or a low-MgO group, corresponding to primary magmatic and secondary metamorphic (or alteration) plagioclases, respectively. The line labeled "primary magmatic" suggests a differentiation trend reflecting $\mathrm{Mg}$ depletion in the interstitial melt with progressive crystallization. $\mathrm{B}$. FeO vs. An content. Note that the calcic plagioclases generally fall into two groups, analogous to the pattern seen in Figure $2 \mathrm{~A}$. The line labeled "primary magmatic" suggests a differentiation trend reflecting $\mathrm{Fe}$ enrichment in the interstitial melt as crystallization proceeded.

gioclase rims (yellow) near the vein. The latter feature is more apparent in Plate 1, Figure 2, the same field of view as in Plate 1, Figure 1, but taken with a filter that suppresses the normal plagioclase luminescence, revealing the dramatic presence of calcic plagioclase rims in the vein halo.

In vein halos, alteration patches, and rocks exhibiting strong background alteration, primary plagioclase laths are commonly altered along microcracks to albite or oligoclase (Table 1). Fluid inclusions in albite are present but are not as abundant as in the calcic rims. Other phases that also form veinlike replacement along fractures within plagioclase include laumontite and chlorite. These minerals cut both primary plagioclase and calcic rims; thus, they are related temporally to secondary albite.

Combined with observations of the Leg 111,137 , and 140 samples, the distribution of calcic secondary plagioclase in Hole 504B is limited to depths exceeding about $1500 \mathrm{mbsf}$ (Fig. 1). The appearance of calcic plagioclase downhole correlates roughly with increases in, but not the first appearance of, both hydrothermal clinopyroxene and magnesio-hornblende.

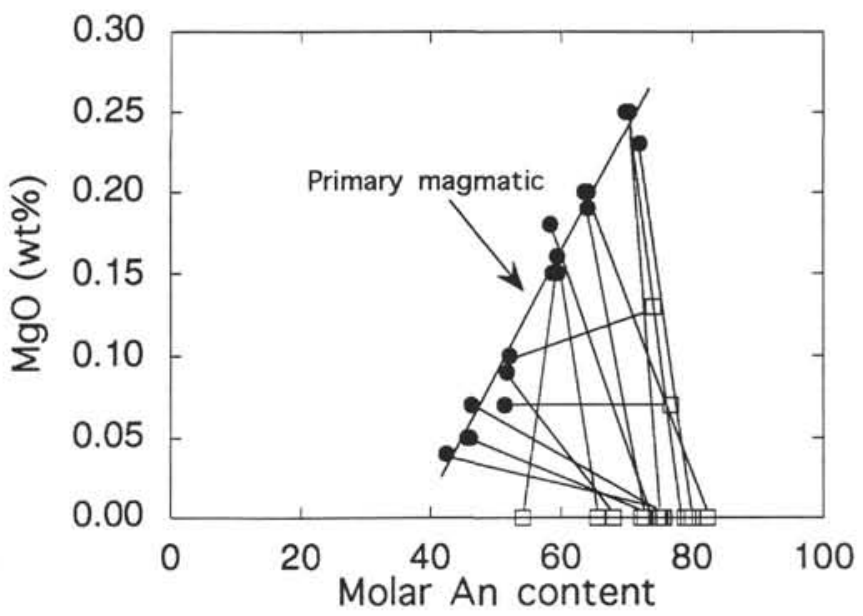

Figure 3. Plot showing electron microprobe determinations of $\mathrm{MgO}$ vs. molar An content for points that were positioned with the aid of cathodoluminescence photomicrographs. For each pair of analyses connected by a tie line, the open symbol represents the cathodoluminescent secondary rim of a plagioclase lath, and the solid symbol represents the immediately adjacent primary plagioclase. The two spots are usually within several tens of micrometers of each other. The primary plagioclase is commonly a sodic outer zone of a normally zoned lath. In all but one case, the cathodoluminescent rim is more calcic than the primary plagioclase and the rims are impoverished in $\mathrm{MgO}$ relative to the primary igneous laths. Line labeled "primary magmatic" is the same as that shown in Figure $2 \mathrm{~A}$.

\section{Amphibole}

Amphibole is widespread throughout the Leg 148 section. It occurs as an alteration product of igneous clinopyroxene and fills vugs, patches, and veins (Shipboard Scientific Party, 1993). Amphibole also occurs in interstitial groundmass areas, where no clear relationships to primary clinopyroxene can be identified. Amphibole replacing clinopyroxene generally occurs as pseudomorphs or fine-grained fibers growing from the pyroxene crystal rims. In alteration patches amphibole is usually associated with chlorite, albite, titanite, \pm epidote.

Amphibole-bearing veins, with or without chlorite, occur throughout the Leg 148 section of Hole 504B (Shipboard Scientific Party, 1993). Structurally, the veins are typically 1 to $2 \mathrm{~mm}$ wide; may be planar, sinuous, or stepped; and may meet with T-shaped intersections. The internal fabric of the amphibole veins is marked by the occurrence of both coarse-grained fibers connecting the opposing walls of a vein and fine-grained fibrous amphibole that fills the centers of veins and the interstitial spaces between the coarse-grained fibers. The coarse fibers have orientations strongly controlled by that of pyroxene crystals in the wall rock, suggesting that coarse amphibole grows syntaxially upon the pyroxene. Being in optical continuity across the veins, the coarse fibers may represent the "stretched" crystal fibers of Ramsay and Huber (1983), and may therefore be syntectonic. Many amphibole veins contain evidence of reopening, with kinked and broken coarse fibers and interstices filled in by randomly oriented fine-grained amphibole fibers. The latter apparently grew into void space without a syntaxial control. Some veins, furthermore, have evidence for shear strain and the opening of small tension gashes that are filled by zeolite minerals.

The amphibole-bearing veins are interpreted to have evolved as extensional features in response to either the regional tectonic stress field or to localized stresses due to thermal contraction and hydrofracturing. Fluid circulation through the fractures caused centimeterscale alteration halos to develop flanking most amphibole veins. Repeated opening of fractures and migration of hot fluids along the 
fractures and into the adjacent wall rock probably took place at the paleo-ridge axis, where tectonic, thermal contraction, and hydrothermal convection processes were all concentrated early in the history of Hole 504B.

One-hundred eighty-three amphibole analyses were conducted by electron microprobe (Table 2). These were all recalculated using a scheme that assumes 15 cations per 23-oxygen formula unit, excluding $\mathrm{K}$, and partitions ferrous and ferric iron to satisfy charge-balance constraints (Robinson et al., 1982). This recalculation is provisional, performed to obtain consistently acceptable formulas for the purpose of classification (Fig. 4). There is considerable uncertainty in the $\mathrm{Fe}^{3+} / \mathrm{Fe}^{2+}$ ratio obtained by this procedure.

The amphiboles are variable in composition, and are generally actinolite, actinolitic-hornblende, and magnesio-hornblende (Fig. 4). Analyses define an array of decreasing $\mathrm{Mg}$ number with increasing $\mathrm{Si}$ atoms per formula unit (and, hence, with decreasing tetrahedral $\mathrm{Al}$ ). Minor elements exhibit the following ranges in oxide weight percent: $\mathrm{TiO}_{2}=0.05-1.65 \mathrm{wt} \%, \mathrm{Al}_{2} \mathrm{O}_{3}=0.78-9.82 \mathrm{wt} \%, \mathrm{MnO}=0.05$ $0.60 \mathrm{wt} \%, \mathrm{Na}_{2} \mathrm{O}=0.15-3.60 \mathrm{wt} \%, \mathrm{~K}_{2} \mathrm{O}=\leq 0.15 \mathrm{wt} \%$, and $\mathrm{Cl}=\leq 0.28$ wt $\%$ ( 107 analyses, and one datum at $0.51 \mathrm{wt} \%$ ).

Amphibole compositions vary slightly with petrographic mode of occurrence (Fig. 5). Vein-filling amphiboles tend to be more actinolitic, whereas amphiboles that replace clinopyroxene or otherwise fill interstitial space in the diabase host rock tend to be more actinolitichornblende and magnesio-hornblende. There is no significant variation of amphibole composition as a function of depth in the Leg 148 lithostratigraphy (Fig. 6).

\section{Secondary Clinopyroxene}

Secondary clinopyroxene is present in sparse amounts in Leg 148 samples, similar to the distribution described from the Leg $137 / 140$ samples (Laverne et al., 1995). The secondary pyroxene is present in two of the studied thin sections along the walls of amphibole-bearing veins, forming a very thin (several micrometers) light green rim grown syntaxially on wall-rock augite. Analyses (Table 3 ) show that magmatic augites are compositionally distinct from the light green, clear, secondary pyroxenes (diopsidic augite), which plot within the field of secondary diopsides defined by earlier studies of Hole 504B (Fig. 7; one analysis thought to be secondary and plotted as such in Fig. 7 is probably magmatic, based upon its chemical composition). Chemical characteristics of five analyzed pyroxenes (assuming that the one analysis is misidentified), which agree with a larger number of observations from Legs 137/140 samples, are as follows: magmatic pyroxene has $\mathrm{Al}_{2} \mathrm{O}_{3} \geq 3 \mathrm{wt} \%, \mathrm{Cr}_{2} \mathrm{O}_{3} \geq 0.25 \mathrm{wt} \%$, and $\mathrm{Na}_{2} \mathrm{O} \leq 0.2$ wt $\%$; whereas secondary pyroxene has $\mathrm{Al}_{2} \mathrm{O}_{3} \leq 1.4 \mathrm{wt} \%, \mathrm{Cr}_{2} \mathrm{O}_{3} \leq$ $0.15 \mathrm{wt} \%$, and $\mathrm{Na}_{2} \mathrm{O} \geq 2.9 \mathrm{wt} \%$.

\section{Chlorite}

Chlorite and mixed-layer chlorite-smectite occur as major minerals in chlorite-actinolite veins, as well as a common mineral replacement in the diabase host rock. The petrographic occurrence is identical to that described for the Legs 137/140 samples (Shipboard Scientific Party, 1993; Laverne et al., 1995). Electron microprobe analyses of chlorite (Table 4) indicate compositions similar to those determined for the sheeted dikes from Legs 137 and 140 (Fig. 8), plotting in the pycnochlorite field of the Hey (1954) classification.

\section{Other Minerals}

Other secondary mineral phases for which electron microprobe data have been collected include talc, epidote, titanite, and apatite. Analyses of these minerals reveal compositions identical to those reported for the immediately overlying sheeted dikes sampled during Legs 137 and 140 (Laverne et al., 1995). The epidote compositions correspond to molar pistacite contents $\left(\mathrm{Fe}^{3+} /\left[\mathrm{Al}+\mathrm{Fe}^{3+}\right]\right)$ of between 0.19 and 0.27 (Table 5; four analyses).

\section{DISCUSSION \\ Geothermometry}

The geothermometric constraints from the mineral chemistry of Leg 148 Hole 504B rocks are identical to those discussed by Laverne et al. (1995) for the Legs 137/140 samples. These constraints are imprecise and are based upon imperfect assumptions of mineral equilibrium. For example, interpreting secondary clinopyroxene compositions with the aid of experimental data (Lindsley and Anderson, 1983) suggests clinopyroxene growth at temperatures of $500^{\circ}$ to $700^{\circ} \mathrm{C}$, although the large proportions of minor elements force these estimates to have uncertainties, commonly of up to $\pm 110^{\circ} \mathrm{C}$, and the absence of coexisting orthopyroxene makes any temperature estimate a minimum (Laverne et al., 1995). Thus, the origin and formation temperature of early-generation secondary diopside remain uncertain. Participation of a deuteric fluid seems probable (Laverne, 1987; Laverne et al., 1995).

Amphibole-plagioclase thermometry helps constrain the temperatures of early hydrothermal interaction that produced magnesiohornblende plus calcic secondary plagioclase. Laverne et al. (1995) concluded that temperatures of $400^{\circ}$ to $500^{\circ} \mathrm{C}$ are most likely for this assemblage. Uncertainties exist, however, because (1) the amphibole-plagioclase "thermometer" is largely empirical and has an uncertainty of at least $\pm 50^{\circ} \mathrm{C}$ (Spear, 1980), and (2) replacement reactions are incomplete and questions remain about how mineral chemistry is influenced by the mineral being replaced. For example, the systematically distinct amphibole compositions between veins and wall rocks might be because vein amphiboles are space-filling, whereas wall rock amphiboles are replacing preexisting clinopyroxene. The general trend from hornblende in wall rocks to actinolite in veins may thus be a function of mode of occurrence, and not of decreasing temperature.

Chlorite-smectite chemistry yields estimates of equilibration temperatures ranging from $50^{\circ}$ to $280^{\circ} \mathrm{C}$ (using the Cathelineau [1988] method based upon chlorite from geothermal wells), similar to results from the Legs 137/140 samples (Laverne et al., 1995). Uncertainties in the published method of at least $\pm 50^{\circ} \mathrm{C}$, as well as questions about equilibrium, make this geothermometer subject to potential error.

Laumontite has an upper thermal stability, relative to wairakite + water, of about $230^{\circ} \mathrm{C}$ at 500 bars of water pressure (Liou, 1971). Although there is no recognized evidence, laumontite might be a replacement of preexisting wairakite in Hole 504B samples.

Even accepting these caveats, there is general evidence that the earliest alteration assemblage of hornblende plus calcic plagioclase represents high temperatures characteristic of the mid-ocean-ridge reaction zone. Later generations of actinolite + chlorite + albite and epidote + quartz most likely formed at lower temperatures during the waning of axial hydrothermal activity.

\section{Constraints on the Reaction Zone}

Modern black smoker temperatures range from about $250^{\circ}$ to $>400^{\circ} \mathrm{C}$ (Von Damm, 1990). Following correction for conductive heat loss and adiabatic cooling on ascent, it is not unreasonable to suggest that in the reaction zone, at depths of 1 to $2 \mathrm{~km}$ below the seafloor, temperatures are near the $400^{\circ}$ to $500^{\circ} \mathrm{C}$ inferred from Hole 504B hornblende-plagioclase equilibria.

Earlier theoretical studies of equilibrium phase assemblages (e.g.. Bowers et al., 1988) tended to focus on albite as part of the secondary phase assemblage that buffers black smoker chemistry in the reaction zone. More recently, however, Berndt and Seyfried (1993) have presented experimental evidence that calcium-enriched hydrothermal 


\begin{tabular}{|c|c|c|c|c|c|c|c|c|c|c|c|c|c|c|c|}
\hline $\begin{array}{l}\text { Core, section: } \\
\text { Interval }(\mathrm{cm}) \text { : }\end{array}$ & $\begin{array}{c}239 \mathrm{R}-1 \\
45-51\end{array}$ & $\begin{array}{c}239 \mathrm{R}-1 \\
45-51\end{array}$ & $\begin{array}{c}239 \mathrm{R}-1 \\
45-51\end{array}$ & $\begin{array}{c}240 \mathrm{R}-1 \\
82-90\end{array}$ & $\begin{array}{c}240 \mathrm{R}-1 \\
82-90\end{array}$ & $\begin{array}{l}240 \mathrm{R}-1 \\
82-90\end{array}$ & $\begin{array}{c}240 \mathrm{R}-1 \\
82-90\end{array}$ & $\begin{array}{l}24 I R-1 \\
32-36\end{array}$ & $\begin{array}{c}241 \mathrm{R}-1 \\
32-36\end{array}$ & $\begin{array}{l}24 I \mathrm{R}-1 \\
32-36\end{array}$ & $\begin{array}{c}241 \mathrm{R}-1 \\
32-36\end{array}$ & $\begin{array}{c}241 \mathrm{R}-1 \\
32-36\end{array}$ & $\begin{array}{l}245 R-1 \\
21-24\end{array}$ & $\begin{array}{c}245 R-1 \\
21-24\end{array}$ & $\begin{array}{l}245 R-1 \\
21-24\end{array}$ \\
\hline Depth (mbsf): & 2000.9 & 2000.9 & 2000.9 & 2007.7 & 2007.7 & 2007.7 & 2007.7 & 2016.8 & 2016.8 & 2016.8 & 2016.8 & 2016.8 & 2043.0 & 2043.0 & 2043.0 \\
\hline Analysis no.: & M10 & M17 & M20 & V3A & V7A & V8A & $\mathrm{V} 31 \mathrm{~A}$ & $\mathrm{~V} 36 \mathrm{~A}$ & $\mathrm{~V} 42 \mathrm{~A}$ & $\mathrm{~V} 43 \mathrm{~A}$ & $\mathrm{~V} 47 \mathrm{~A}$ & V $52 \mathrm{~A}$ & $\mathrm{~V} 21 \mathrm{~A}$ & $\mathrm{~V} 31 \mathrm{~A}$ & V $37 \mathrm{~A}$ \\
\hline Occurrence: & Vein & Halo & $\begin{array}{l}\text { Dark } \\
\text { rock }\end{array}$ & $\begin{array}{c}\text { Vein } \\
\text { matrix }\end{array}$ & Halo & Halo & $\begin{array}{l}\text { In } \\
\text { chlorite } \\
\text { patch }\end{array}$ & $\begin{array}{l}\text { Vein edge } \\
\text { on clino- } \\
\text { pyroxene }\end{array}$ & $\begin{array}{l}\text { Vein } \\
\text { core }\end{array}$ & $\begin{array}{c}\text { Breccia } \\
\text { clast }\end{array}$ & $\begin{array}{l}\text { Breccia } \\
\text { matrix }\end{array}$ & $\begin{array}{l}\text { Out of } \\
\text { breccia }\end{array}$ & $\begin{array}{l}\text { Ground- } \\
\text { mass }\end{array}$ & $\begin{array}{l}\text { Vein } \\
\text { wall }\end{array}$ & Halo \\
\hline $\mathrm{SiO}_{2}$ & 48.49 & 48.20 & 49.72 & 49.12 & 50.15 & 51.22 & 53.77 & 53.61 & 52.94 & 50.55 & 51.02 & 50.29 & 50.48 & 53.05 & 51.50 \\
\hline $\mathrm{TiO}_{2}$ & 0.29 & 0.45 & 0.36 & 0.57 & 0.47 & 0.46 & 0.65 & 0.09 & 0.09 & 0.15 & 0.27 & 0.22 & 0.31 & 0.62 & 0.54 \\
\hline $\mathrm{Al}_{2} \mathrm{O}_{3}$ & 3.75 & 4.06 & 2.25 & 6.56 & 5.57 & 5.15 & 3.78 & 1.79 & 1.49 & 4.31 & 4.31 & 4.88 & 5.55 & 2.86 & 4.47 \\
\hline $\mathrm{FeO}^{\circ}$ & 18.94 & 16.34 & 18.79 & 14.38 & 13.71 & 14.25 & 9.15 & 15.76 & 16.96 & 15.93 & 15.36 & 15.50 & 15.18 & 14.37 & 15.01 \\
\hline $\mathrm{MnO}$ & 0.21 & 0.19 & 0.32 & 0.18 & 0.22 & 0.24 & 0.05 & 0.33 & 0.35 & 0.24 & 0.34 & 0.29 & 0.21 & 0.32 & 0.33 \\
\hline $\mathrm{MgO}$ & 11.66 & 13.59 & 12.93 & 13.76 & 14.89 & 14.48 & 18.60 & 13.85 & 14.39 & 12.87 & 14.09 & 12.73 & 14.98 & 15.44 & 14.65 \\
\hline $\mathrm{CaO}$ & 11.68 & 11.50 & 10.16 & 11.67 & 10.90 & 10.75 & 11.29 & 11.40 & 10.14 & 11.90 & 11.26 & 11.95 & 9.21 & 10.73 & 11.15 \\
\hline $\mathrm{Na}_{2} \mathrm{O}$ & 0.48 & 0.62 & 0.51 & 0.99 & 0.82 & 0.79 & 0.90 & 0.21 & 0.47 & 0.47 & 0.75 & 0.68 & 0.75 & 0.58 & 0.67 \\
\hline $\mathrm{K}_{2} \mathrm{O}$ & 0.02 & 0.02 & 0.02 & 0.07 & 0.07 & 0.03 & 0.04 & 0.01 & 0.02 & 0.02 & 0.05 & 0.01 & 0.03 & 0.05 & 0.06 \\
\hline $\mathrm{Cl}$ & 0.00 & 0.00 & 0.00 & 0.11 & 0.03 & 0.07 & 0.10 & 0.08 & 0.05 & 0.21 & 0.06 & 0.09 & 0.05 & 0.16 & 0.10 \\
\hline Total & 95.52 & 94.97 & 95.06 & 97.30 & 96.80 & 97.37 & 98.23 & 97.05 & 96.85 & 96.44 & 97.45 & 96.55 & 96.70 & 98.02 & 98.38 \\
\hline $\mathrm{Si}$ & 7.276 & 7.163 & $\begin{array}{r}7.475 \\
0.300\end{array}$ & 7.058 & 7.220 & 7.360 & 7.470 & 7.844 & $\begin{array}{l}7.750 \\
0.750\end{array}$ & 7.425 & 7.362 & 7.358 & 7.296 & 7.592 & 7.351 \\
\hline $\mathrm{Al}^{3+}$ & 0.664 & 0.712 & 0.399 & 0.942 & 0.780 & 0.640 & 0.530 & 0.156 & 0.250 & 0.575 & 0.638 & 0.642 & 0.704 & 0.408 & 0.649 \\
\hline $\begin{array}{l}\mathrm{Fe}^{3+3} \\
\text { Sum in } \mathrm{T}\end{array}$ & 0.061 & 0.125 & 0.126 & 0.000 & 0.000 & 0.000 & 0.000 & 0.000 & 0.000 & 0.000 & 0.000 & 0.000 & 0.000 & 0.000 & 0.000 \\
\hline Sum in $\mathrm{T}$ & 8.000 & 8.000 & 8.000 & 8.000 & 8.000 & 8.000 & 8.000 & 8.000 & 8.000 & 8.000 & 8.000 & 8.000 & 8.000 & 8.000 & 8.000 \\
\hline $\begin{array}{l}\mathrm{Al} \\
\mathrm{Fe}^{3+}\end{array}$ & $\begin{array}{l}0.000 \\
0.795\end{array}$ & $\begin{array}{l}0.000 \\
0.911\end{array}$ & $\begin{array}{l}0.000 \\
0.589\end{array}$ & $\begin{array}{l}0.170 \\
0.913\end{array}$ & $\begin{array}{l}0.166 \\
0.728\end{array}$ & $\begin{array}{l}0.233 \\
0.523\end{array}$ & $\begin{array}{l}0.089 \\
0.541\end{array}$ & $\begin{array}{l}0.153 \\
0.040\end{array}$ & $\begin{array}{l}0.007 \\
0.353\end{array}$ & $\begin{array}{l}0.172 \\
0.499\end{array}$ & $\begin{array}{l}0.095 \\
0.685\end{array}$ & $\begin{array}{l}0.201 \\
0.584\end{array}$ & $\begin{array}{l}0.242 \\
0.599\end{array}$ & $\begin{array}{l}0.075 \\
0.351\end{array}$ & $\begin{array}{l}0.103 \\
0.604\end{array}$ \\
\hline $\mathrm{Ti}$ & 0.033 & 0.050 & 0.041 & $\begin{array}{l}0.913 \\
0.062\end{array}$ & 0.051 & 0.050 & $\begin{array}{l}0.041 \\
0.068\end{array}$ & 0.010 & $\begin{array}{l}0.333 \\
0.010\end{array}$ & $\begin{array}{l}0.4917 \\
0.017\end{array}$ & $\begin{array}{l}0.083 \\
0.029\end{array}$ & $\begin{array}{l}0.024 \\
0.024\end{array}$ & 0.034 & 0.067 & $\begin{array}{l}0.0048 \\
0.058\end{array}$ \\
\hline $\mathrm{Mg}$ & 2.607 & 3.010 & 2.897 & 2.947 & 3.195 & 3.101 & 3.851 & 3.020 & 3.139 & 2.817 & 3.030 & 2.776 & 3.227 & 3.293 & 3.116 \\
\hline $\mathrm{Fe}^{2+}$ & 1.521 & 0.995 & 1.474 & 0.815 & 0.860 & 1.094 & 0.451 & 1.776 & 1.491 & 1.458 & 1.160 & 1.313 & 0.898 & 1.214 & 1.118 \\
\hline $\mathrm{Mn}$ & 0.027 & 0.024 & 0.000 & 0.022 & 0.000 & 0.000 & 0.000 & 0.000 & 0.000 & 0.030 & 0.000 & 0.036 & 0.000 & 0.000 & 0.000 \\
\hline $\mathrm{Ca}$ & 0.017 & 0.010 & 0.000 & 0.073 & 0.000 & 0.000 & 0.000 & 0.000 & 0.000 & 0.007 & 0.000 & 0.066 & 0.000 & 0.000 & 0.000 \\
\hline Sum in $\mathrm{C}$ & 5.000 & 5.000 & 5.000 & 5.000 & 5.000 & 5.000 & 5.000 & 5.000 & 5.000 & 5.000 & 5,000 & 5.000 & 5.000 & 5.000 & 5.000 \\
\hline $\mathrm{Fe}^{2+}$ & 0.000 & 0.000 & 0.174 & 0,000 & 0.063 & 0.096 & 0.071 & 0.112 & 0.233 & 0.000 & 0.008 & 0.000 & 0.338 & 0.155 & 0.069 \\
\hline $\mathrm{Mn}$ & 0.000 & 0.000 & 0.041 & 0.000 & 0.027 & 0.029 & 0.006 & 0.041 & 0.043 & 0.000 & 0.042 & 0.000 & 0.026 & 0.039 & 0.040 \\
\hline $\mathrm{Ca}$ & 1.860 & 1.821 & 1.637 & 1.724 & 1.682 & 1.655 & 1.681 & 1.787 & 1.591 & 1.866 & 1.741 & 1.807 & 1.426 & 1.645 & 1.705 \\
\hline $\mathrm{Na}$ & 0.140 & 0.179 & 0.149 & 0.276 & 0.229 & 0.220 & 0.242 & 0.060 & 0.133 & 0.134 & 0.210 & 0.193 & 0.210 & 0.161 & 0.185 \\
\hline Sum in B & 2.000 & 2.000 & 2.000 & 2.000 & 2.000 & 2.000 & 2.000 & 2.000 & 2.000 & 2.000 & 2.000 & 2.000 & 2.000 & 2.000 & 2.000 \\
\hline $\begin{array}{l}\mathrm{K} \\
\text { Sum in } \mathrm{A}\end{array}$ & $\begin{array}{l}0.004 \\
0.004\end{array}$ & $\begin{array}{l}0.004 \\
0.004\end{array}$ & $\begin{array}{l}0.004 \\
0.004\end{array}$ & $\begin{array}{l}0.013 \\
0.013\end{array}$ & $\begin{array}{l}0.013 \\
0.013\end{array}$ & $\begin{array}{l}0.005 \\
0.005\end{array}$ & $\begin{array}{l}0.007 \\
0.007\end{array}$ & $\begin{array}{l}0.002 \\
0.002\end{array}$ & $\begin{array}{l}0.004 \\
0.004\end{array}$ & $\begin{array}{l}0.004 \\
0.004\end{array}$ & $\begin{array}{l}0.009 \\
0.009\end{array}$ & $\begin{array}{l}0.002 \\
0.002\end{array}$ & $\begin{array}{l}0.006 \\
0.006\end{array}$ & $\begin{array}{l}0.009 \\
0.009\end{array}$ & $\begin{array}{l}0.011 \\
0.011\end{array}$ \\
\hline $\mathrm{Cl}$ & 0.000 & 0.000 & 0.000 & 0.027 & 0.007 & 0.017 & 0.024 & 0.020 & 0.012 & 0.052 & 0.015 & 0.022 & 0.012 & 0.039 & 0.024 \\
\hline
\end{tabular}

Notes: $\mathrm{FeO}$ indicates all $\mathrm{Fe}$ calculated as $\mathrm{FeO}$. 
Table 2 (continued).

\begin{tabular}{|c|c|c|c|c|c|c|c|c|c|c|c|c|c|c|c|c|c|}
\hline $\begin{array}{l}\text { Core, section: } \\
\text { Interval }(\mathrm{cm}) \text { : }\end{array}$ & $\begin{array}{c}246 \mathrm{R}-1 \\
26-30\end{array}$ & $\begin{array}{c}246 \mathrm{R}-1 \\
26-30\end{array}$ & $\begin{array}{l}246 \mathrm{R}-1 \\
91-94\end{array}$ & $\begin{array}{l}246 \mathrm{R}-1 \\
91-94\end{array}$ & $\begin{array}{l}246 \mathrm{R}-1 \\
91-94\end{array}$ & $\begin{array}{l}246 \mathrm{R}-1 \\
91-94\end{array}$ & $\begin{array}{c}247 \mathrm{R}-1 \\
36-4.3\end{array}$ & $\begin{array}{l}247 R-1 \\
36-43\end{array}$ & $\begin{array}{c}25 \mid R-1 \\
5-9\end{array}$ & $\begin{array}{c}251 \mathrm{R}-1 \\
5-9\end{array}$ & $\begin{array}{c}252 \mathrm{R}-1 \\
0-4\end{array}$ & $\begin{array}{c}252 \mathrm{R}-1 \\
0-4\end{array}$ & $\begin{array}{c}252 R-1 \\
0-4\end{array}$ & $\begin{array}{c}252 R-1 \\
15-20\end{array}$ & $\begin{array}{c}252 \mathrm{R}-1 \\
15-20\end{array}$ & $\begin{array}{l}252 \mathrm{R}-1 \\
29-33\end{array}$ & $\begin{array}{l}252 R-1 \\
29-33\end{array}$ \\
\hline Depth (mbsf): & 2052.5 & 2052.5 & 2053.1 & 2053.1 & 2053.1 & 2053.1 & 2057.2 & 2057.2 & 2090.0 & 2090.0 & 2099.4 & 2099.4 & 2099.4 & 2099.6 & 2099.6 & 2099.7 & 2099.7 \\
\hline Analysis no.: & M4I & M43 & VIA & $\mathrm{V} 3 \mathrm{~A}$ & V8A & $\mathrm{V} 12 \mathrm{~A}$ & P2084 & P2093 & M64 & M69 & P2026 & P2060 & P2062 & M71 & M77 & B7013 & B7017 \\
\hline Occurrence: & $\begin{array}{l}\text { Dark } \\
\text { rock }\end{array}$ & Patch & $\begin{array}{c}\text { Ground- } \\
\text { mass }\end{array}$ & Halo & $\begin{array}{l}\text { Vein } \\
\text { core }\end{array}$ & $\begin{array}{l}\text { Vein } \\
\text { core }\end{array}$ & Halo & Vein & $\begin{array}{l}\text { Dark } \\
\text { rock }\end{array}$ & Vein & Halo & Vein & $\begin{array}{l}\text { Ground- } \\
\text { mass }\end{array}$ & Patch & Vug & Halo & Halo \\
\hline $\begin{array}{l}\mathrm{SiO}_{2} \\
\mathrm{TiO}_{2} \\
\mathrm{Al}_{2} \mathrm{O}_{3} \\
\mathrm{FOO} \\
\mathrm{MnO} \\
\mathrm{MgO} \\
\mathrm{CaO} \\
\mathrm{Na}_{2} \mathrm{O} \\
\mathrm{K}_{2} \mathrm{O} \\
\mathrm{Cl} \\
\text { Total }\end{array}$ & $\begin{array}{r}49.10 \\
0.11 \\
3.87 \\
15.33 \\
0.25 \\
15.37 \\
10.28 \\
0.51 \\
0.01 \\
0.00 \\
94.83\end{array}$ & $\begin{array}{r}49.28 \\
0.29 \\
3.35 \\
15.37 \\
0.34 \\
14.71 \\
11.22 \\
0.61 \\
0.01 \\
0.00 \\
95.18\end{array}$ & $\begin{array}{r}49.91 \\
0.29 \\
7.28 \\
1.38 \\
0.23 \\
14.16 \\
11.17 \\
1.10 \\
0.03 \\
0.09 \\
98.55\end{array}$ & $\begin{array}{r}51.36 \\
0.59 \\
5.04 \\
12.72 \\
0.20 \\
15.96 \\
11.49 \\
1.00 \\
0.02 \\
0.16 \\
98.38\end{array}$ & $\begin{array}{r}53.05 \\
0.19 \\
2.34 \\
17.22 \\
0.28 \\
13.17 \\
10.43 \\
0.39 \\
0.06 \\
0.19 \\
97.13\end{array}$ & $\begin{array}{r}51.90 \\
0.32 \\
3.98 \\
14.92 \\
0.27 \\
14.54 \\
10.94 \\
0.62 \\
0.03 \\
0.08 \\
97.52\end{array}$ & $\begin{array}{r}50.13 \\
0.56 \\
5.68 \\
12.83 \\
0.21 \\
14.62 \\
11.27 \\
0.81 \\
0.02 \\
0.00 \\
96.13\end{array}$ & $\begin{array}{r}51.70 \\
0.29 \\
4.07 \\
12.08 \\
0.21 \\
15.70 \\
11.08 \\
0.67 \\
0.00 \\
0.00 \\
95.80\end{array}$ & $\begin{array}{r}50.63 \\
0.17 \\
1.46 \\
13.69 \\
0.46 \\
14.14 \\
16.14 \\
0.24 \\
0.00 \\
0.00 \\
96.93\end{array}$ & $\begin{array}{r}50.85 \\
0.15 \\
0.88 \\
23.01 \\
0.50 \\
14.12 \\
5.22 \\
0.56 \\
0.00 \\
0.00 \\
95.29\end{array}$ & $\begin{array}{r}51.16 \\
0.54 \\
3.73 \\
1.27 \\
0.09 \\
14.72 \\
10.82 \\
0.70 \\
0.01 \\
0.00 \\
96.04\end{array}$ & $\begin{array}{r}48.70 \\
0.41 \\
5.39 \\
13.72 \\
0.22 \\
13.74 \\
11.22 \\
0.86 \\
0.00 \\
0.00 \\
94.26\end{array}$ & $\begin{array}{r}50.10 \\
0.58 \\
4.90 \\
12.40 \\
0.29 \\
17.49 \\
8.60 \\
0.90 \\
0.06 \\
0.00 \\
95.32\end{array}$ & $\begin{array}{r}51.24 \\
0.26 \\
2.54 \\
10.61 \\
0.27 \\
18.59 \\
11.48 \\
0.70 \\
0.01 \\
0.00 \\
95.70\end{array}$ & $\begin{array}{r}47.43 \\
0.47 \\
5.73 \\
13.65 \\
0.29 \\
15.37 \\
11.33 \\
1.10 \\
0.00 \\
0.00 \\
95.37\end{array}$ & $\begin{array}{r}53.65 \\
0.07 \\
2.30 \\
12.69 \\
0.28 \\
16.04 \\
11.38 \\
0.35 \\
0.00 \\
0.00 \\
96.76\end{array}$ & $\begin{array}{r}50.17 \\
0.31 \\
6.03 \\
12.70 \\
0.26 \\
14.85 \\
10.54 \\
1.06 \\
0.01 \\
0.00 \\
95.93\end{array}$ \\
\hline $\begin{array}{l}\mathrm{Si} \\
\mathrm{Al} \\
\mathrm{Fe}^{3+} \\
\text { Sum in } \mathrm{T}\end{array}$ & $\begin{array}{l}7.243 \\
0.673 \\
0.084 \\
8.000\end{array}$ & $\begin{array}{l}7.267 \\
0.583 \\
0.150 \\
8.000\end{array}$ & $\begin{array}{l}7.053 \\
0.947 \\
0.000 \\
8.000\end{array}$ & $\begin{array}{l}7.228 \\
0.772 \\
0.000 \\
8.000\end{array}$ & $\begin{array}{l}7.790 \\
0.210 \\
0.000 \\
8.000\end{array}$ & $\begin{array}{l}7.476 \\
0.524 \\
0.000 \\
8.000\end{array}$ & $\begin{array}{l}7.259 \\
0.741 \\
0.000 \\
8.000\end{array}$ & $\begin{array}{l}7.488 \\
0.512 \\
0.000 \\
8.000\end{array}$ & $\begin{array}{l}7.362 \\
0.250 \\
0.387 \\
8.000\end{array}$ & $\begin{array}{l}7.674 \\
0.157 \\
0.169 \\
8.000\end{array}$ & $\begin{array}{l}7.460 \\
0.540 \\
0.000 \\
8.000\end{array}$ & $\begin{array}{l}7.219 \\
0.781 \\
0.000 \\
8.000\end{array}$ & $\begin{array}{l}7.229 \\
0.771 \\
0.000 \\
8.000\end{array}$ & $\begin{array}{l}7.327 \\
0.428 \\
0.244 \\
8.000\end{array}$ & $\begin{array}{l}6.882 \\
0.981 \\
0.138 \\
8.000\end{array}$ & $\begin{array}{l}7.735 \\
0.265 \\
0.000 \\
8.000\end{array}$ & $\begin{array}{l}7.247 \\
0.753 \\
0.000 \\
8.000\end{array}$ \\
\hline $\begin{array}{l}\mathrm{Al}^{2} \\
\mathrm{Fe}^{3+} \\
\mathrm{Ti}^{2} \\
\mathrm{Mg}^{2+} \\
\mathrm{Fe}^{2+} \\
\mathrm{Mn} \\
\mathrm{Ca} \\
\text { Sum in } \mathrm{C}\end{array}$ & $\begin{array}{l}0.000 \\
0.877 \\
0.012 \\
3.379 \\
0.732 \\
0.000 \\
0.000 \\
5.000\end{array}$ & $\begin{array}{l}0.000 \\
0.841 \\
0.032 \\
3.233 \\
0.894 \\
0.000 \\
0.000 \\
5.000\end{array}$ & $\begin{array}{l}0.267 \\
0.914 \\
0.031 \\
2.982 \\
0.785 \\
0.020 \\
0.000 \\
5.000\end{array}$ & $\begin{array}{l}0.064 \\
0.853 \\
0.062 \\
3.347 \\
0.644 \\
0.024 \\
0.005 \\
5.000\end{array}$ & $\begin{array}{l}0.195 \\
0.073 \\
0.021 \\
2.882 \\
1.829 \\
0.000 \\
0.000 \\
5.000\end{array}$ & $\begin{array}{l}0.152 \\
0.470 \\
0.035 \\
3.121 \\
1.222 \\
0.000 \\
0.000 \\
5.000\end{array}$ & $\begin{array}{l}0.229 \\
0.614 \\
0.061 \\
3.155 \\
0.939 \\
0.002 \\
0.000 \\
5.000\end{array}$ & $\begin{array}{l}0.183 \\
0.454 \\
0.032 \\
3.389 \\
0.942 \\
0.000 \\
0.000 \\
5.000\end{array}$ & $\begin{array}{l}0.000 \\
0.668 \\
0.019 \\
3.064 \\
0.610 \\
0.057 \\
0.583 \\
5.000\end{array}$ & $\begin{array}{l}0.000 \\
0.456 \\
0.017 \\
3.176 \\
1.352 \\
0.000 \\
0.000 \\
5.000\end{array}$ & $\begin{array}{l}0.102 \\
0.516 \\
0.059 \\
3.199 \\
1.124 \\
0.000 \\
0.000 \\
5.000\end{array}$ & $\begin{array}{l}0.161 \\
0.776 \\
0.046 \\
3.035 \\
0.925 \\
0.028 \\
0.029 \\
5.000\end{array}$ & $\begin{array}{l}0.063 \\
0.823 \\
0.063 \\
3.761 \\
0.290 \\
0.000 \\
0.000 \\
5.000\end{array}$ & $\begin{array}{l}0.000 \\
0.809 \\
0.028 \\
3.962 \\
0.201 \\
0.000 \\
0.000 \\
5.000\end{array}$ & $\begin{array}{l}0.000 \\
1.325 \\
0.051 \\
3.324 \\
0.193 \\
0.036 \\
0.071 \\
5.000\end{array}$ & $\begin{array}{l}0.126 \\
0.222 \\
0.008 \\
3.446 \\
1.198 \\
0.000 \\
0.000 \\
5.000\end{array}$ & $\begin{array}{l}0.275 \\
0.706 \\
0.034 \\
3.197 \\
0.789 \\
0.000 \\
0.000 \\
5.000\end{array}$ \\
\hline $\begin{array}{l}\mathrm{Fe}^{2+} \\
\mathrm{Mn} \\
\mathrm{Ca} \\
\mathrm{Na} \\
\text { Sum in } \mathrm{B}\end{array}$ & $\begin{array}{l}0.198 \\
0.031 \\
1.625 \\
0.146 \\
2.000\end{array}$ & $\begin{array}{l}0.010 \\
0.042 \\
1.773 \\
0.174 \\
2.000\end{array}$ & $\begin{array}{l}0.000 \\
0.007 \\
1.691 \\
0.301 \\
2.000\end{array}$ & $\begin{array}{l}0.000 \\
0.000 \\
1.727 \\
0.273 \\
2.000\end{array}$ & $\begin{array}{l}0.213 \\
0.035 \\
1.641 \\
0.111 \\
2.000\end{array}$ & $\begin{array}{l}0.105 \\
0.033 \\
1.689 \\
0.173 \\
2.000\end{array}$ & $\begin{array}{l}0.000 \\
0.024 \\
1.749 \\
0.227 \\
2.000\end{array}$ & $\begin{array}{l}0.067 \\
0.026 \\
1.719 \\
0.188 \\
2.000\end{array}$ & $\begin{array}{l}0.000 \\
0.000 \\
1.932 \\
0.068 \\
2.000\end{array}$ & $\begin{array}{l}0.928 \\
0.064 \\
0.844 \\
0.164 \\
2.000\end{array}$ & $\begin{array}{l}0.100 \\
0.011 \\
1.691 \\
0.198 \\
2.000\end{array}$ & $\begin{array}{l}0.000 \\
0.000 \\
1.753 \\
0.247 \\
2.000\end{array}$ & $\begin{array}{l}0.383 \\
0.035 \\
1.330 \\
0.252 \\
2.000\end{array}$ & $\begin{array}{l}0.014 \\
0.033 \\
1.759 \\
0.194 \\
2.000\end{array}$ & $\begin{array}{l}0.000 \\
0.000 \\
1.691 \\
0.309 \\
2.000\end{array}$ & $\begin{array}{l}0.110 \\
0.034 \\
1.758 \\
0.098 \\
2.000\end{array}$ & $\begin{array}{l}0.040 \\
0.032 \\
1.631 \\
0.297 \\
2.000\end{array}$ \\
\hline $\begin{array}{l}\mathrm{K} \\
\text { Sum in } \mathrm{A}\end{array}$ & $\begin{array}{l}0.002 \\
0.002\end{array}$ & $\begin{array}{l}0.002 \\
0.002\end{array}$ & $\begin{array}{l}0.005 \\
0.005\end{array}$ & $\begin{array}{l}0.004 \\
0.004\end{array}$ & $\begin{array}{l}0.011 \\
0.011\end{array}$ & $\begin{array}{l}0.006 \\
0.006\end{array}$ & $\begin{array}{l}0.004 \\
0.004\end{array}$ & $\begin{array}{l}0.000 \\
0.000\end{array}$ & $\begin{array}{l}0.000 \\
0.000\end{array}$ & $\begin{array}{l}0.000 \\
0.000\end{array}$ & $\begin{array}{l}0.002 \\
0.002\end{array}$ & $\begin{array}{l}0.000 \\
0.000\end{array}$ & $\begin{array}{l}0.011 \\
0.011\end{array}$ & $\begin{array}{l}0.002 \\
0.002\end{array}$ & $\begin{array}{l}0.000 \\
0.000\end{array}$ & $\begin{array}{l}0.000 \\
0.000\end{array}$ & $\begin{array}{l}0.002 \\
0.002\end{array}$ \\
\hline $\mathrm{Cl}$ & 0.000 & 0.000 & 0.022 & 0.038 & 0.047 & 0.020 & 0.000 & 0.000 & 0.000 & 0.000 & 0.000 & 0.000 & 0.000 & 0.000 & 0.000 & 0.000 & 0.000 \\
\hline
\end{tabular}




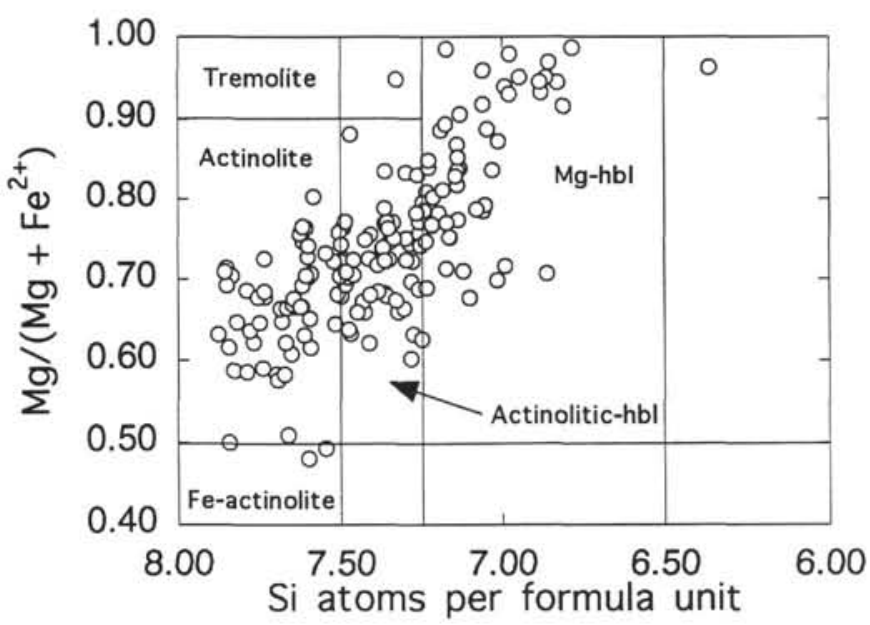

Figure 4. $\mathrm{Mg} /\left(\mathrm{Mg}+\mathrm{Fe}^{2+}\right)$ vs. Si atoms per formula unit for Leg 148 amphiboles compared with the classification scheme for calcic amphiboles (Leake, 1978). $\mathrm{Mg}-\mathrm{hbl}=$ magnesio-hornblende, Actinolitic-hbl = actinolitic hornblende, and Fe-Actinolite $=$ ferroactinolite

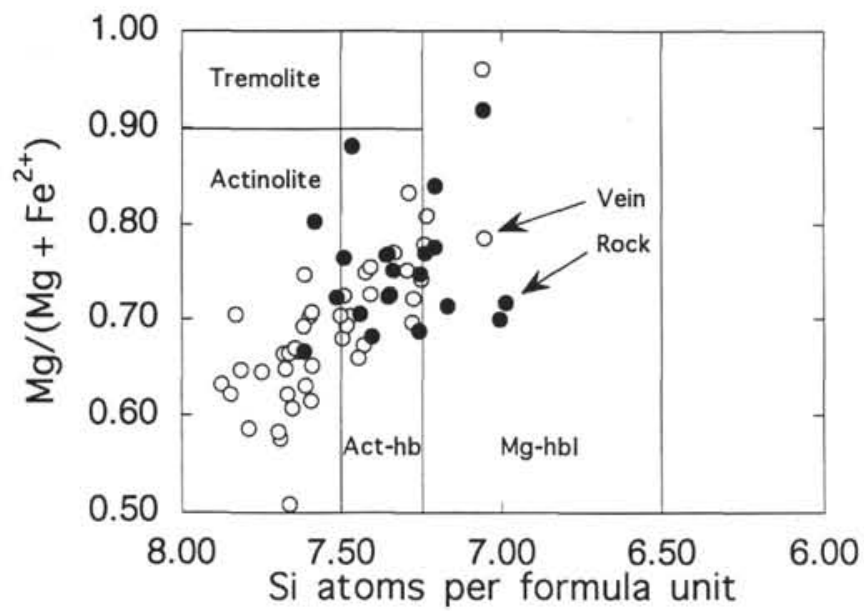

Figure 5. Plot of selected electron microprobe analyses of Leg 148 amphibole, keyed to the occurrence either in amphibole-bearing veins or as a secondary phase in diabase (usually after clinopyroxene). In general, amphiboles in veins tend to be more actinolitic, whereas those in the host rock are slightly more aluminous and tend to be actinolitic-hornblende or magnesio-hornblende. $\mathrm{Mg}-\mathrm{hbl}=$ magnesio-hornblende and $\mathrm{Act}-\mathrm{hb}=$ actinolitic hornblende.

fluids are more likely to be equilibrated with a calcic plagioclase (labradorite) at $400^{\circ} \mathrm{C}, 400$ bars, and within the axial reaction zone. The calcic secondary plagioclase ranging from $\mathrm{An}_{55}$ through $\mathrm{An}_{94}$, with the majority near $\mathrm{An}_{80}$, discovered in Hole $504 \mathrm{~B}$ seems to provide confirmation of the more recent experimental studies. The presence of calcic plagioclase in the high-temperature alteration assemblage challenges the widely held notion, based upon oft-sampled altered basalts, diabases, and spilites, that the dominant plagioclase of the mid-ocean-ridge reaction zone is albite. Evidence from Hole 504B suggests that albite is a later plagioclase in the reaction zone, which formed during waning hydrothermal conditions.

If calcic secondary plagioclase is a general petrographic characteristic of mid-ocean-ridge axial reaction zones, then the deep sheeted dikes of Hole 504B, below about $1500 \mathrm{mbsf}$, represent our only recognized samples of this zone. Previously dredged diabasic rocks lack this reaction zone feature, perhaps because these samples are of the upper sheeted dike complex analogous to the Leg 83 samples.

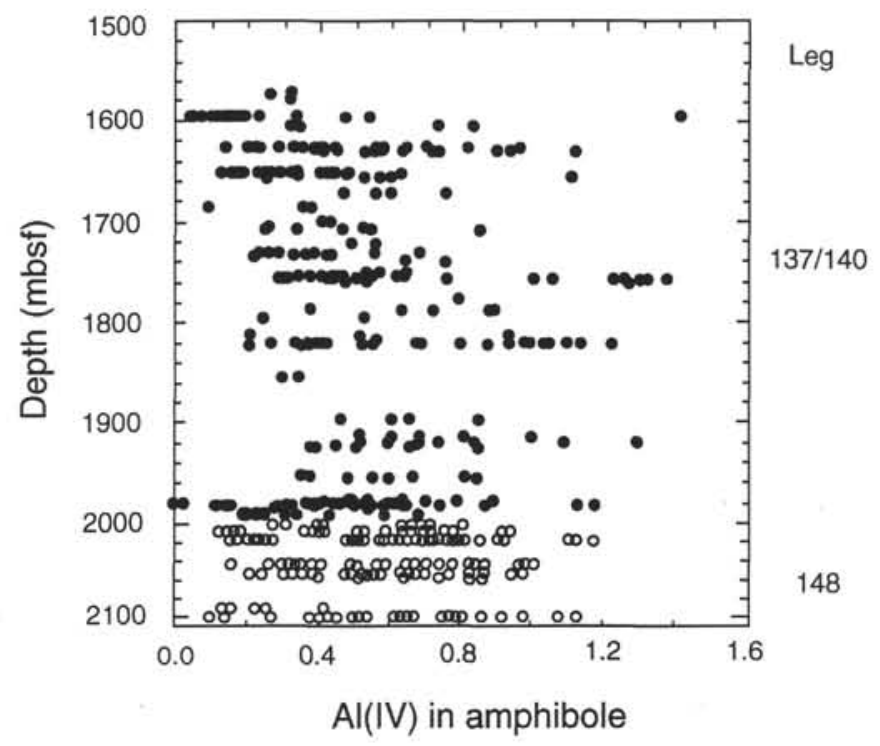

Figure 6. Plot showing the tetrahedral aluminum content of Leg 148 amphibole (open symbols), estimated from electron microprobe analysis, as a function of sample depth. Note that individual samples exhibit wide ranges in $\mathrm{Al}(\mathrm{IV})$ and that there is no apparent change with depth. Solid symbols represent Legs 137/140 amphibole compositions for comparison (Laverne et al., 1995).

Table 3. Representative electron microprobe analyses of clinopyroxene (wt \%), Hole 504B (Leg 148).

\begin{tabular}{|c|c|c|c|c|c|}
\hline Core, section: & $251 \mathrm{R}-1$ & 25IR-1 & $251 \mathrm{R}-1$ & 252R-1 & $252 \mathrm{R}-1$ \\
\hline Interval $(\mathrm{cm})$ : & $5-9$ & $5-9$ & $5-9$ & $0-4$ & $0-4$ \\
\hline Analysis no.: & B7047 & B7048 & B7051 & P2056 & P2057 \\
\hline Type: & Secondary & Secondary & Secondary & Magmatic & Magmatic \\
\hline \multicolumn{6}{|l|}{ Oxides: } \\
\hline $\mathrm{SiO}_{2}$ & 52.27 & 52.79 & 52.33 & 50.52 & 50.97 \\
\hline $\mathrm{TiO}_{2}$ & 0.48 & 0.47 & 0.62 & 0.44 & 0.46 \\
\hline $\mathrm{Al}_{2} \overline{\mathrm{O}}_{3}$ & 3.01 & 0.68 & 1.38 & 3.76 & 3.47 \\
\hline $\mathrm{Cr}_{2} \mathrm{O}_{3}$ & 0.26 & 0.09 & 0.15 & 0.53 & 0.49 \\
\hline $\mathrm{FeO}^{*}$ & 6.29 & 12.25 & 12.39 & 5.73 & 5.40 \\
\hline $\mathrm{MnO}$ & 0.03 & 0.16 & 0.25 & 0.03 & 0.13 \\
\hline $\mathrm{MgO}$ & 17.76 & 10.99 & 11.11 & 16.64 & 16.73 \\
\hline $\mathrm{CaO}$ & 18.68 & 17.29 & 17.29 & 19.97 & 20.63 \\
\hline $\mathrm{Na}_{2} \mathrm{O}$ & 0.21 & 3.77 & 2.91 & 0.21 & 0.19 \\
\hline $\mathrm{K}_{2} \mathrm{O}$ & 0.00 & 0.00 & 0.00 & 0.00 & 0.00 \\
\hline Total & 98.99 & 98.49 & 98.43 & 97.83 & 98.47 \\
\hline \multicolumn{6}{|l|}{ Cations: } \\
\hline $\mathrm{Si}$ & 1.926 & 2.023 & 2.004 & 1.892 & 1.897 \\
\hline $\mathrm{Ti}$ & 0.013 & 0.014 & 0.018 & 0.012 & 0.013 \\
\hline Al & 0.131 & 0.031 & 0.062 & 0.166 & 0.152 \\
\hline $\mathrm{Cr}$ & 0.008 & 0.003 & 0.005 & 0.016 & 0.014 \\
\hline $\mathrm{Fe}$ & 0.194 & 0.393 & 0.397 & 0.179 & 0.168 \\
\hline $\mathrm{Mn}$ & 0.001 & 0.005 & 0.008 & 0.001 & 0.004 \\
\hline $\mathrm{Mg}$ & 0.975 & 0.628 & 0.634 & 0.929 & 0.928 \\
\hline $\mathrm{Ca}$ & 0.737 & 0.710 & 0.709 & 0.801 & 0.823 \\
\hline $\mathrm{Na}$ & 0.015 & 0.280 & 0.216 & 0.015 & 0.014 \\
\hline K & 0.000 & 0.000 & 0.000 & 0.000 & 0.000 \\
\hline Sum & 3.999 & 4.086 & 4.053 & 4.012 & 4.013 \\
\hline Wo & 38.7 & 40.9 & 40.6 & 41.9 & 42.8 \\
\hline En & 51.1 & 36.2 & 36.3 & 48.6 & 48.3 \\
\hline Fs & 10.2 & 22.9 & 23.2 & 9.4 & 9.0 \\
\hline
\end{tabular}

Note: $\mathrm{FeO}^{*}$ indicates all $\mathrm{Fe}$ calculated as $\mathrm{FeO}$.

More problematic is the fact that several features of the Hole 504B sheeted dikes are absent from descriptions of sheeted dike complexes from ophiolites. Secondary calcic plagioclase and abundant millimeter-scale amphibole veins are unknown and uncommon, respectively, in ophiolites. In the Oman ophiolite, Nehlig and Juteau (1988) described only epidote + quartz veins in sheeted dikes, where- 


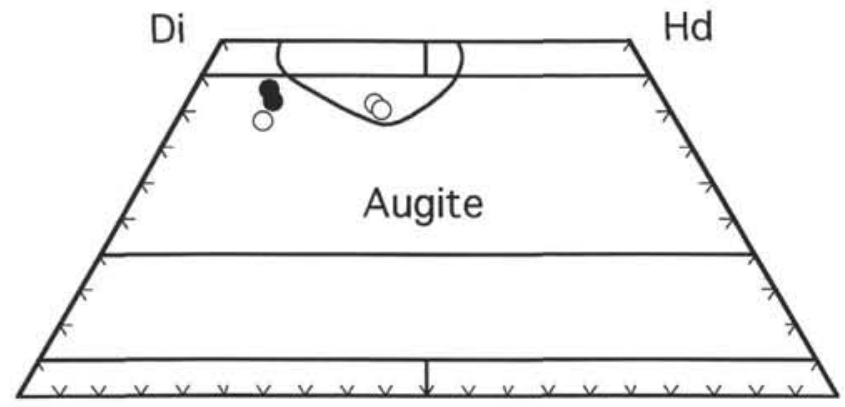

En

Figure 7. Plot of quadrilateral pyroxene components in Leg 148 diabase estimated from electron microprobe analyses. Solid symbols represent magmatic augite, whereas the open symbols represent light green secondary clinopyroxene. Note that one point originally thought to be secondary is probably misidentified and is, in fact, magmatic. The solid curved line encloses the field of secondary clinopyroxene (mostly diopside) determined for Leg 140 diabase samples, for comparison.

as amphibole veins are confined to the gabbroic units. In the Josephine ophiolite, Alexander and Harper (1992) described hornblendebearing veins in the transition zone from the sheeted dikes to the underlying gabbros, with veins in the gabbro more abundant than in the dike complex. Finally, ophiolite occurrences of epidosite (e.g., Richardson et al., 1987), thought possibly to represent products of the reaction zone, are rare or absent in Hole 504B and in oceanic sample suites altogether. Epidosites may represent focused upflow zones where high water/rock ratios and wholesale replacement of diabase are achieved, in contrast to the sheeted dikes from Hole 504B, which represent a region where fluids in excess of $400^{\circ} \mathrm{C}$ promoted low water/rock ratio reactions with diabase.

In conclusion, this chapter presents new mineral chemical data for the deep sheeted dike complex of Hole 504B. The rocks sampled during Leg 148 are nearly identical in their alteration characteristics to those recovered during Legs $137 / 140$ and described by Laverne et al. (1995) and others in the Legs 137/140 Scientific Reports (Erzinger, Becker, Dick, and Stokking, 1995). We propose that the deep diabases recovered during Legs 137, 140, and 148 represent samples of rock that were altered in the axial hydrothermal reaction zone and were subsequently advected off-axis and subjected to a cooling, more passive, hydrothermal regime. Evidence from these rocks for early hydrothermal mineral reactions and processes, therefore, may serve as firm ground-truth for speculations about the reaction zone derived from theoretical, experimental, and related ophiolite studies. Further studies at Hole 504B are required to advance our understanding of this reaction zone. In particular, the proximity to and the nature of the postulated diabase/gabbro transition are still completely unknown.

\section{ACKNOWLEDGMENTS}

We thank the Master and crew of the SEDCO BP471, as well as the TAMU drilling crew and the Catermar stewards for making our experiences together during Legs 140 and 148 truly enjoyable and productive. This research was supported by the National Science Foundation and JOI/USSSP to D.A.V. and J.C.A. and by CNRSINSU to C.L. We thank Sarah Vegotsky for assistance in cathodoluminescence and other data collection, Bob Bodnar for providing unrequited beam time on the laser Raman microprobe at Virginia Tech, and Marcel Bohn for his "unalterable" assistance with the microprobe in Brest. This paper benefitted from the review comments of Catherine Mevel, and Richard J. Arculus, for which we are grateful.

\section{REFERENCES}

Alexander, R.J., and Harper, G.D., 1992. The Josephine ophiolite: an ancient analogue for slow- to intermediate-spreading oceanic ridges. In Parson, L.M., Murton, B.J., and Browning, P. (Eds.), Ophiolites and Their Modern Oceanic Analogues. Geol. Soc. Spec. Publ. London, 60:3-38.

Alt, J.C., Anderson, T.F., and Bonnell, L., 1989a. The geochemistry of sulfur in a $1.3 \mathrm{~km}$ section of hydrothermally altered oceanic crust, DSDP Hole 504B. Geochim. Cosmochim. Acta, 53:1011-1023.

Alt, J.C., Anderson, T.F., Bonnell, L., and Muehlenbachs, K., 1989b. Mineralogy, chemistry, and stable isotopic compositions of hydrothermally altered sheeted dikes: ODP Hole 504B, Leg 111. In Becker, K., Sakai, H., et al., Proc, ODP, Sci. Results, 111: College Station, TX (Ocean Drilling Program), 27-40.

Alt, J.C., Honnorez, J., Laverne, C., and Emmermann, R., 1986a. Hydrothermal alteration of a I $\mathrm{km}$ section through the upper oceanic crust, Deep Sea Drilling Project Hole 504B: mineralogy, chemistry, and evolution of seawater-basalt interactions. J. Geophys. Res., 91:10309-10335.

Alt, J.C., Laverne, C., and Muehlenbachs, K., 1985. Alteration of the upper oceanic crust: mineralogy and processes in Deep Sea Drilling Project Hole 504B, Leg 83. In Anderson, R.N., Honnorez, J., Becker, K., et al., Init. Repts. DSDP, 83: Washington (U.S. Govt. Printing Office), $217-$ 247.

Alt, J.C., Muehlenbachs, K., and Honnorez, J., 1986b. An oxygen isotopic profile through the upper kilometer of the oceanic crust, DSDP Hole 504B. Earth Planet. Sci. Lett., 80:217-229.

Anderson, R.N., Honnorez, J., Becker, K., Adamson, A.C., Alt, J.C., Emmermann, R., Kempton, P.D., Kinoshita, H., Laverne, C., Mottl, M.J., and Newmark, R.L., 1982. DSDP Hole 504B, the first reference section over $1 \mathrm{~km}$ through Layer 2 of the oceanic crust. Nature, 300:589-594.

Anderson, R.N., Honnorez, J., Becker, K., et al., 1985. Init. Repts. DSDP. 83: Washington (U.S. Govt. Printing Office).

Becker, K., Sakai, H., et al., 1988. Proc. ODP, Init. Repts., 111 : College Station, TX (Ocean Drilling Program).

1989. Proc. ODP, Sci. Results, 111: College Station, TX (Ocean Drilling Program).

Berndt, M.E., and Seyfried, W.E., Jr., 1993. Ca and Na exchange during hydrothermal alteration of calcic plagioclase at $400^{\circ} \mathrm{C}$ and 400 bars. Geochim. Cosmochim. Acta, 57:4445-4451.

Bowers, T.S., Campbell, A.C., Measures, C.I., Spivack, A.J., Khadem, M., and Edmond, J.M., 1988. Chemical controls on the composition of vent fluids at $13^{\circ} \mathrm{N}-11^{\circ} \mathrm{N}$ and $21^{\circ} \mathrm{N}$, East Pacific Rise. J.Geophys. Res., 93:4522-4536.

Cathelineau, M., 1988. Cation site occupancy in chlorites and illites as a function of temperature. Clay Mineral., 23:471-485.

Erzinger, J., Becker, K., Dick, H.J.B., and Stokking, L.B. (Eds.), 1995. Proc. ODP, Sci. Results, 137/140: College Station, TX (Ocean Drilling Program).

Helz, R.T., 1987. Differentiation behavior of Kileauea Iki lava lake, Kilauea volcano, Hawaii: an overview of past and present work. In Mysen, B.O. (Ed.), Magmatic Processes: Physiochemical Principles. Geochem. Soc. Spec. Publ., 1:241-258.

Hey, M.H., 1954. A new review of the chlorites. Mineral. Mag., 30:277.

Honnorez, J., Laverne, C., Hubberten, H.-W., Emmermann, R., and Muehlenbachs, K., 1983. Alteration processes in Layer 2 basalts from Deep Sea Drilling Project Hole 504B, Costa Rica Rift. In Cann, J.R., Langseth, M.G., Honnorez, J., Von Herzen, R.P., White, S.M., et al., Init. Repts. DSDP, 69: Washington (U.S. Govt. Printing Office), 509-546.

Kelley, D.S., Vanko, D.A., and Gu, C., 1995. Fluid evolution in oceanic crustal layer 2: fluid inclusion evidence from the sheeted dike complex, Hole 504B, Costa Rica Rift. In Erzinger, J., Becker, K., Dick, H.J.B., and Stokking, L.B. (Eds.), Proc. ODP, Sci. Results, 137/140: College Station, TX (Ocean Drilling Program), 191-205.

Laverne, C., 1987. Unusual occurrence of aegirine-augite, fassaite and melanite in oceanic basalts (DSDP Hole 504B). Lithos, 20:135-151.

Laverne, C., Alt, J.C., and Honnorez, J., 1989. Transition entre l'altération à basse température et le métamorphisme hydrothermale de la croûte océanique: étude pétrographique et géochemique du puits 504B, Est-Pacifique. Bull. Soc. Geol. Fr., 8:327-337.

Laverne, C., Vanko, D.A., Tartarotti, P., and Alt, J.C., 1995. Chemistry and geothermometry of secondary minerals from the deep sheeted dike complex, Hole 504B. In Erzinger, J., Becker, K., Dick, H.J.B., and Stokking, L.B. (Eds.), Proc. ODP, Sci. Results, 137/140: College Station, TX (Ocean Drilling Program), 167-189. 
Leake, B.E., 1978. Nomenclature of amphiboles. Am. Mineral., 63:10231052.

Lindsley, D.H., and Anderson, D.J., 1983. A two-pyroxene thermometer.. . Geophys. Res., 88(Suppl.):A887-A906.

Liou, J.G.. 1971. Pressure-temperature stabilities of laumontite, wairakite, lawsonite, and related minerals in the system $\mathrm{CaAl}_{2} \mathrm{Si}_{2} \mathrm{O}_{8}-\mathrm{H}_{2} \mathrm{O} . J$. Petrol., 12:379-411.

Marshall, D.J., 1988. Cathodoluminescence of Geological Materials; Boston (Unwin Hyman).

Mora, C.I., and Ramseyer, K., 1992. Cathodoluminescence of coexisting plagioclases, Boehls Butte anorthosite: CL activators and fluid flow paths. Am. Mineral., 77:1258-1265.

Nehlig. P., and Juteau, T., 1988. Flow porosities, permeabilities and preliminary data on fluid inclusions and fossil thermal gradients in the crustal sequence of the Sumail ophiolite (Oman). Tectonophysics, 151:199-221.

Ramsay, J.G., and Huber, M., 1983. The Techniques of Modern Structural Geology (Vol. 1): Strain Analysis: London (Academic Press).

Richardson. C.J., Cann, J.R., Richards, H.G., and Cowan, J.G., 1987. Metaldepleted root zones of the Troodos ore-forming hydrothermal systems, Cyprus. Earth Planet. Sci. Lett., 84:243-253.

Robinson, P.. Spear, F.S., Schumacher, J.C., Laird, J., Klein, C., Evans, B.W., and Doolan, B.L., 1982. Phase relations of metamorphic amphiboles: natural occurrence and theory. In Veblen, D.R., and Ribbe, P.H.
(Eds.), Amphiboles: Petrology and Experimental Phase Relations: Rev. Mineral. 9B: 1-227.

Shipboard Scientific Party, 1988. Site 504: Costa Rica Rift. In Becker, K., Sakai, H., et al., Proc. ODP, Init. Repts., 111: College Station, TX (Ocean Drilling Program), 35-251.

-, 1992a. Site 504. In Becker, K., Foss, G., et al., Proc. ODP, Init. Repts., 137: College Station, TX (Ocean Drilling Program), 15-55. 1992b. Site 504. In Dick, H.J.B., Erzinger, J., Stokking, L.B., et al., Proc. ODP, Init. Repts., 140: College Station, TX (Ocean Drilling Program), 37-200.

, 1993. Site 504. In Alt, J.C., Kinoshita, H., Stokking, L.B., et al., Proc. ODP, Init. Repts., 148: College Station, TX (Ocean Drilling Program), 27-121.

Spear, F.S., 1980. NaSiCaAl exchange equilibrium between plagioclase and amphibole: an empirical model. Contrib. Mineral. Petrol., 72:33-41.

Von Damm, K.L.. 1990. Seafloor hydrothermal activity: black smoker chemistry and chimneys. Annu. Rev. Earth Planet. Sci., 18:173-204.

Date of initial receipt: 17 August 1994

Date of acceptance: 29 January 1995

Ms 148SR-126

Table 4. Representative electron microprobe analyses of chlorite, chlorite-smectite, and talc (wt\%), Hole 504B (Leg 148).

\begin{tabular}{|c|c|c|c|c|c|c|c|c|c|c|c|}
\hline $\begin{array}{l}\text { Core, section: } \\
\text { Interval }(\mathrm{cm}) \text { : }\end{array}$ & $\begin{array}{c}239 \mathrm{R}-1 \\
45-51\end{array}$ & $\begin{array}{c}246 R-1 \\
26-30\end{array}$ & $\begin{array}{c}246 \mathrm{R}-1 \\
26-30\end{array}$ & $\begin{array}{c}246 R-1 \\
66-70\end{array}$ & $\begin{array}{c}25 \mid R-1 \\
5-9\end{array}$ & $\begin{array}{c}251 R-1 \\
5-9\end{array}$ & $\begin{array}{c}251 \mathrm{R}-1 \\
5-9\end{array}$ & $\begin{array}{c}246 \mathrm{R}-1 \\
26-30\end{array}$ & $\begin{array}{c}246 \mathrm{R}-1 \\
26-30\end{array}$ & $\begin{array}{c}246 \mathrm{R}-1 \\
26-30\end{array}$ & $\begin{array}{c}246 R-1 \\
66-70\end{array}$ \\
\hline Point: & M21 & M34 & M36 & M55 & M59 & M61 & M62 & M32 & M38 & M39 & M53 \\
\hline Depth (mbsf): & 20009 & 2052.5 & 2052.5 & 2052.9 & 2090.0 & 2090.0 & 2090.0 & 2052.5 & 2052.5 & 2052.5 & 2052.9 \\
\hline Mineral analyzed: & Chlorite & Chlorite & Chlorite & Chlorite & Chlorite & Chlorite & ML & Talc & Talc & Talc & Talc \\
\hline Phase replaced: & Olivine & Olivine & Olivine & Olivine & & Olivine & Olivine & Olivine & Olivine & Olivine & Olivine \\
\hline Occurrence: & Diabase & Diabase & Diabase & Diabase & Vein & Diabase & Diabase & Diabase & Diabase & Diabase & Diabase \\
\hline $\mathrm{SiO}_{2}$ & 27.82 & 27.47 & 29.32 & 27.68 & 25.62 & 25.66 & 27.39 & 57.42 & 54.61 & 84.52 & 58.3 \\
\hline $\mathrm{Al}_{2} \mathrm{O}_{3}$ & 16.42 & 15.83 & 15.54 & 16.01 & 18.09 & 17.6 & 16.45 & 0.64 & 2.81 & 1.67 & 0.68 \\
\hline $\mathrm{TiO}_{2}$ & 0.01 & 0.02 & 0.03 & 0 & 0.01 & 0 & 0 & 0.01 & 0.14 & 0.05 & 0 \\
\hline $\mathrm{MgO}$ & 18.44 & 21.05 & 23.18 & 20.88 & 17.54 & 17.01 & 18.13 & 30.31 & 24.3 & 7.23 & 29.45 \\
\hline $\mathrm{FeO}^{*}$ & 23.69 & 20.18 & 17.4 & 20.77 & 24.63 & 25.25 & 24.39 & 3.51 & 10.49 & 3.9 & 4.37 \\
\hline $\mathrm{MnO}$ & 0.11 & 0.1 & 0.05 & 0.09 & 0.24 & 0.21 & 0.14 & 0 & 0.05 & 0.03 & 0.01 \\
\hline $\mathrm{CaO}$ & 0.42 & 0.14 & 0.08 & 0.12 & 0.17 & 0.08 & 0.25 & 0.03 & 0.11 & 0.13 & 0.06 \\
\hline $\mathrm{Na}_{2} \mathrm{O}$ & 0.03 & 0.02 & 0.03 & 0 & 0.03 & 0.01 & 0.02 & 0.28 & 0.58 & 0.04 & 0.26 \\
\hline $\mathrm{K}_{2} \overline{\mathrm{O}}$ & 0.02 & 0 & 0.02 & 0.04 & 0.01 & 0.02 & 0.02 & 0.03 & 0.04 & 0.01 & 0.02 \\
\hline Total & 86.96 & 84.81 & 85.67 & 85.59 & 86.34 & 85.84 & 86.79 & 92.23 & 93.13 & 97.58 & 93.14 \\
\hline
\end{tabular}

Note: $\mathrm{FeO}^{*}$ indicates all $\mathrm{Fe}$ calculated as $\mathrm{FeO} . \mathrm{ML}=$ mixed layer chlorite-smectite. 


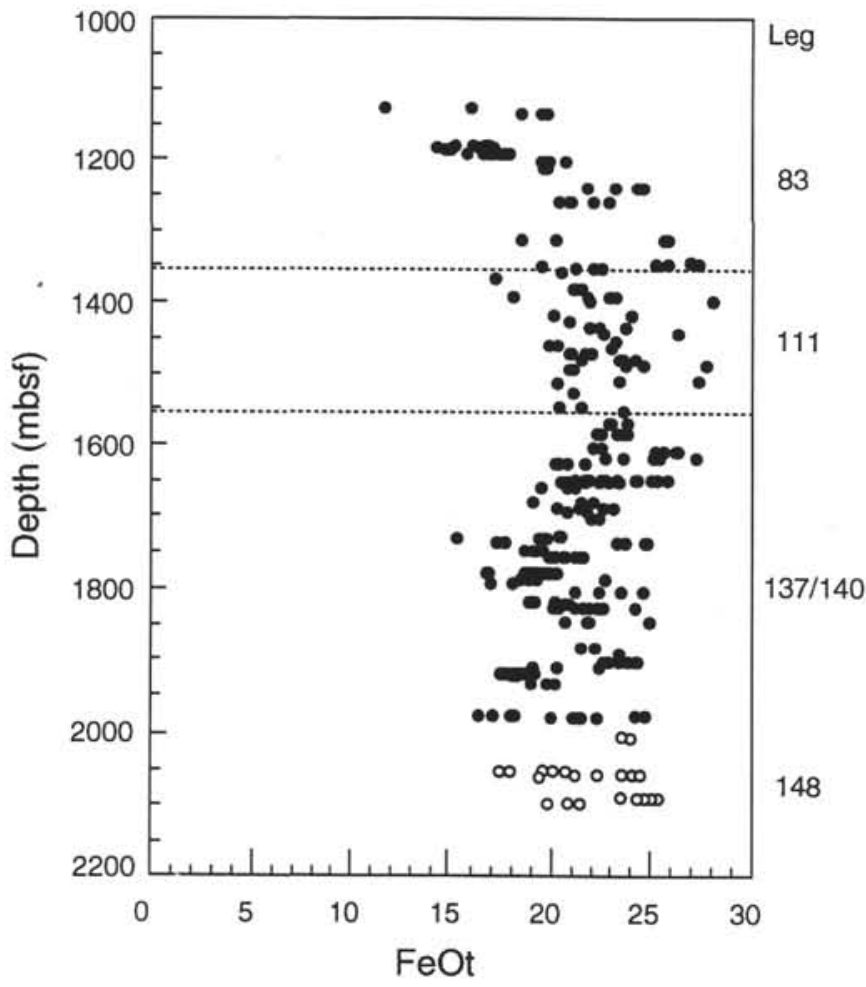

Figure 8. Plot of total $\mathrm{FeO}$ weight percent in chlorites, determined by electron microprobe, vs. sample depth for the transition zone and the sheeted dikes of Hole 504B. The lithostratigraphy of this portion of Hole 504B is shown in Figure 1. Solid symbols are after Laverne et al. (1995), and open symbols are from the present study.
Table 5. Representative electron microprobe analyses of epidote (wt \%), Hole 504B (Leg 148).

\begin{tabular}{|c|c|c|c|c|}
\hline $\begin{array}{l}\text { Core, section: } \\
\text { Interval }(\mathrm{cm}) \text { : }\end{array}$ & $\begin{array}{l}241 \mathrm{R}-1 \\
91-95\end{array}$ & $\begin{array}{c}241 R-1 \\
91-95\end{array}$ & $\begin{array}{c}252 \mathrm{R}-1 \\
0-4\end{array}$ & $\begin{array}{c}252 R-1 \\
0-4\end{array}$ \\
\hline Analysis no.: & P2004 & P2005 & P2508 & P2509 \\
\hline $\begin{array}{l}\text { Oxides: } \\
\mathrm{SiO}_{2} \\
\mathrm{TiO}_{2} \\
\mathrm{Al}_{2} \mathrm{O}_{3} \\
\mathrm{Fe}_{2} \mathrm{O}_{3}^{*} \\
\mathrm{MnO} \\
\mathrm{MgO} \\
\mathrm{CaO} \\
\mathrm{Na}_{2} \mathrm{O} \\
\mathrm{K}_{2} \mathrm{O} \\
\mathrm{Cl}^{\circ} \\
\text { Total }\end{array}$ & $\begin{array}{r}37.13 \\
0.11 \\
24.42 \\
10.94 \\
0.07 \\
0.17 \\
23.12 \\
0.02 \\
0.00 \\
0.00 \\
95.98\end{array}$ & $\begin{array}{r}37.22 \\
0.17 \\
25.58 \\
9.42 \\
0.20 \\
0.06 \\
22.34 \\
0.02 \\
0.00 \\
0.03 \\
95.04\end{array}$ & $\begin{array}{r}36.91 \\
0.08 \\
23.21 \\
13.25 \\
0.07 \\
0.00 \\
23.08 \\
0.00 \\
0.00 \\
0.00 \\
96.60\end{array}$ & $\begin{array}{r}36.13 \\
0.23 \\
23.51 \\
12.87 \\
0.16 \\
0.01 \\
22.58 \\
0.00 \\
0.00 \\
0.00 \\
95.49\end{array}$ \\
\hline $\begin{array}{l}\text { Cations: } \\
\mathrm{Si} \\
\mathrm{Ti} \\
\mathrm{Al} \\
\mathrm{Fe} \\
\mathrm{Mn} \\
\mathrm{Mg} \\
\mathrm{Ca} \\
\mathrm{Na} \\
\mathrm{K} \\
\mathrm{Cl} \\
\mathrm{Sum}\end{array}$ & $\begin{array}{r}5.986 \\
0.013 \\
4.642 \\
1.327 \\
0.010 \\
0.041 \\
3.994 \\
0.006 \\
0.000 \\
0.000 \\
16.019\end{array}$ & $\begin{array}{r}6.010 \\
0.021 \\
4.869 \\
1.145 \\
0.027 \\
0.014 \\
3.865 \\
0.006 \\
0.000 \\
0.008 \\
15.966\end{array}$ & $\begin{array}{r}5.964 \\
0.010 \\
4.421 \\
1.611 \\
0.010 \\
0.000 \\
3.996 \\
0.000 \\
0.000 \\
0.000 \\
16.011\end{array}$ & $\begin{array}{r}5.902 \\
0.028 \\
4.527 \\
1.582 \\
0.022 \\
0.002 \\
3.952 \\
0.000 \\
0.000 \\
0.000 \\
16.016\end{array}$ \\
\hline Pistacite (\%) & 22.2 & 19.0 & 26.7 & 25.9 \\
\hline
\end{tabular}

Note: $\mathrm{Fe}_{2} \mathrm{O}_{3}{ }^{*}$ indicates all $\mathrm{Fe}$ calculated as $\mathrm{Fe}_{2} \mathrm{O}_{3}$. 


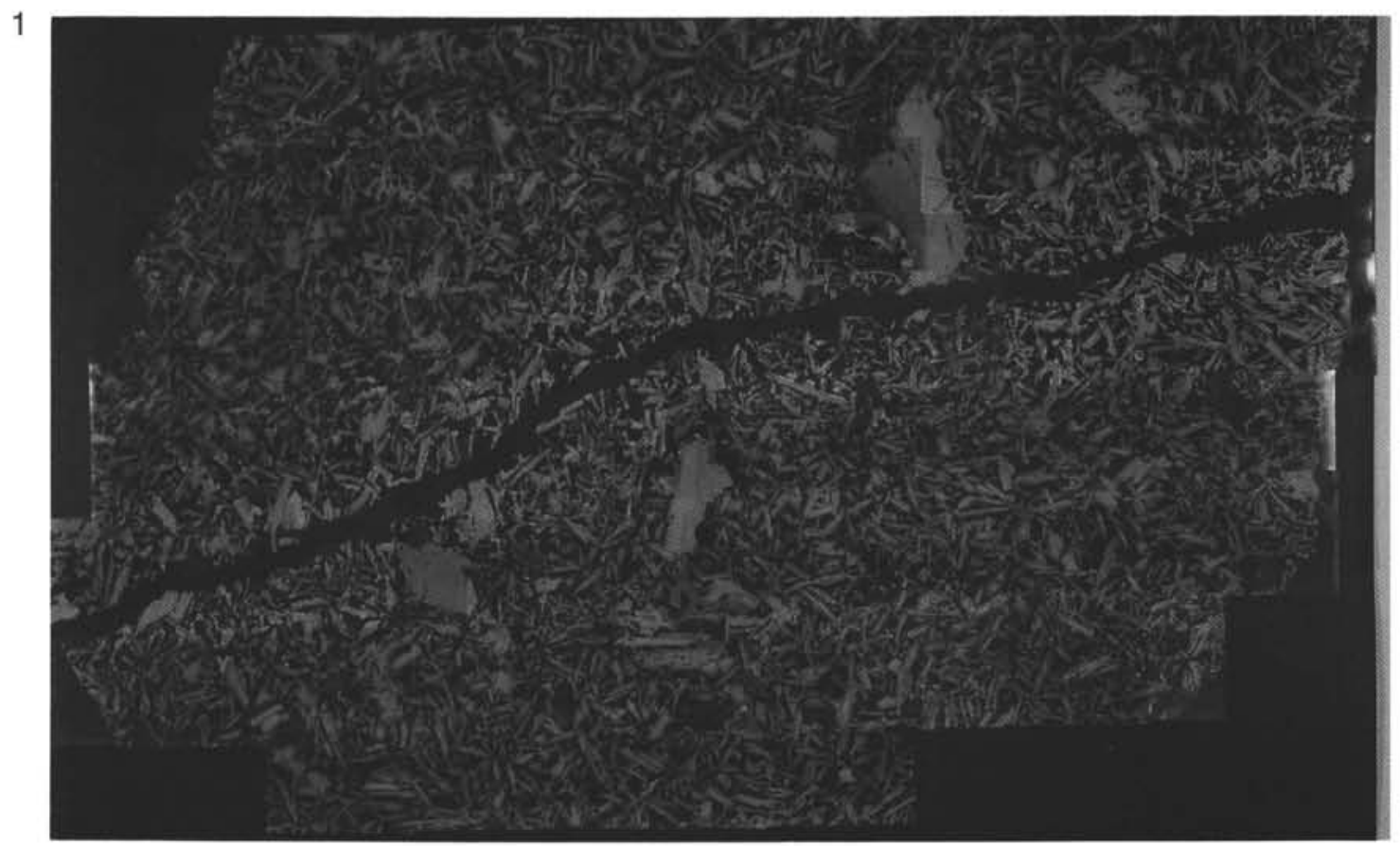

2

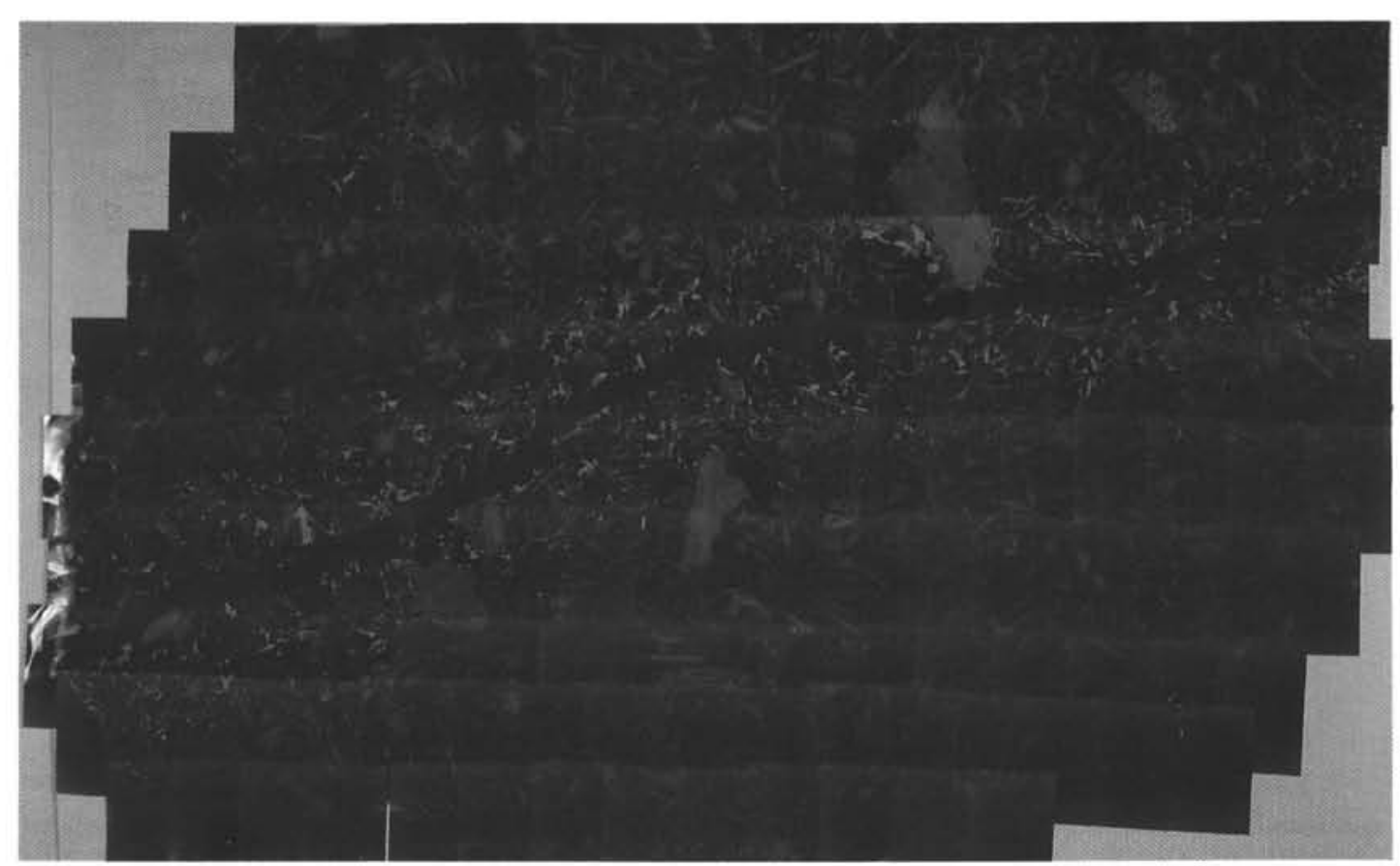

Plate 1. Cathodoluminescence images of Sample 148-504B-246R-1 (Piece 7, 18-21 cm). The area of thin section imaged is $1.5 \times 2.2 \mathrm{~cm}$. Each plate is a mosaic of approximately 150 photomicrographs obtained with a Luminoscope cathodoluminescence stage, mounted on a petrographic microscope with a $4 \times$ objective and a $7 \times$ photo-ocular. See Laverne et al. (1995) for a cathodoluminescence color plate of a similar sample at a larger magnification. 1. Diabase with a crosscutting millimeter-scale actinolite vein. Actinolite and clinopyroxene exhibit no luminescence, whereas plagioclase exhibits variable luminescence as a function of composition. The calcic megacrysts $\left(\mathrm{An}_{75-86}\right)$ are yellowish. Lath-shaped phenocrysts vary from yellowish in their calcic cores to blue-gray in their sodic rims (normal zoning results in the sodic edge zone reaching $\mathrm{An}_{58}$ or lower). Smaller blue laths and overgrowths are more sodic yet, reaching $\mathrm{An} \mathrm{n}_{30}$ or so. Note how the distribution of highly evolved plagioclase is heterogeneous. Barely visible in the photomosaic is an abundance of bright yellow plagioclase rims in the vicinity of the vein. Kodak Gold Ultra 400 film; $15 \mathrm{keV}$ accelerating potential; $0.5 \mathrm{~mA}$ current; exposure approximately $60 \mathrm{~s}$. 2. Identical area as Figure 1. The image was filtered by a coating of hydrocarbon contamination vapor-deposited onto the vacuum side of the upper viewing window. The effect of the filter is to prohibit all but the most intense cathodoluminescent light from reaching the microscope. In this way, the intensely yellow secondary calcic plagioclase rims are visible. This secondary plagioclase is mostly restricted to the vein halo, where it accounts for a few modal percent of the rock. Electron microprobe analyses were placed with the aid of this image: primary/secondary mineral pairs from three laths are $\mathrm{An}_{70} / \mathrm{An}_{76-79}, \mathrm{An}_{64} / \mathrm{An}_{82}, \mathrm{An}_{72} / \mathrm{An}_{80}$, and $\mathrm{An}_{58} / \mathrm{An}_{65-75}$. In each case, the replacement plagioclase is more calcic than the primary plagioclase. Kodak Ultra Gold film; $22 \mathrm{keV}$ accelerating voltage; $0.5 \mathrm{~mA}$ current; exposure approximately $60 \mathrm{~s}$. 
The following plate is reprinted from Laverne et al. (1995) in full color.

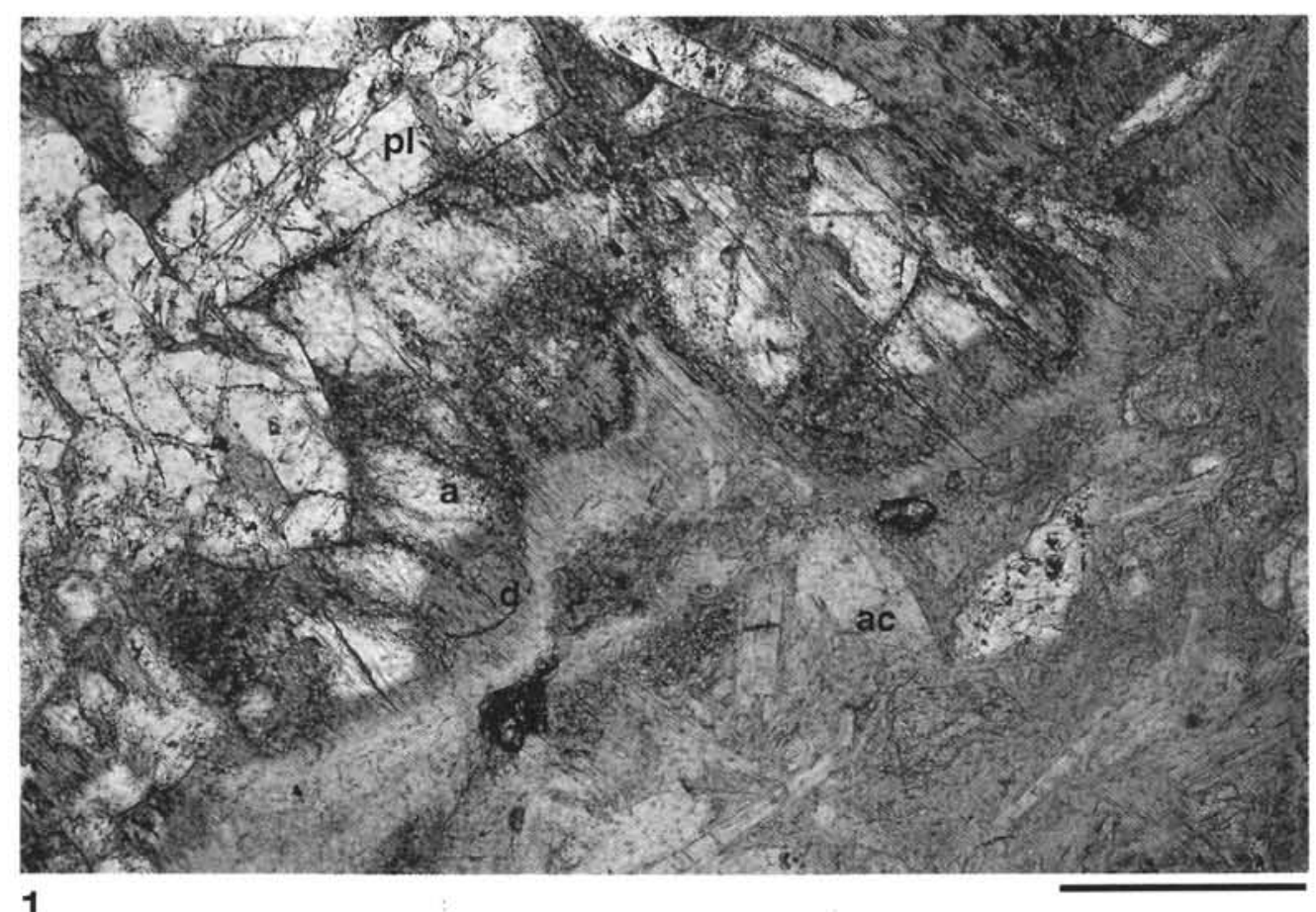

1

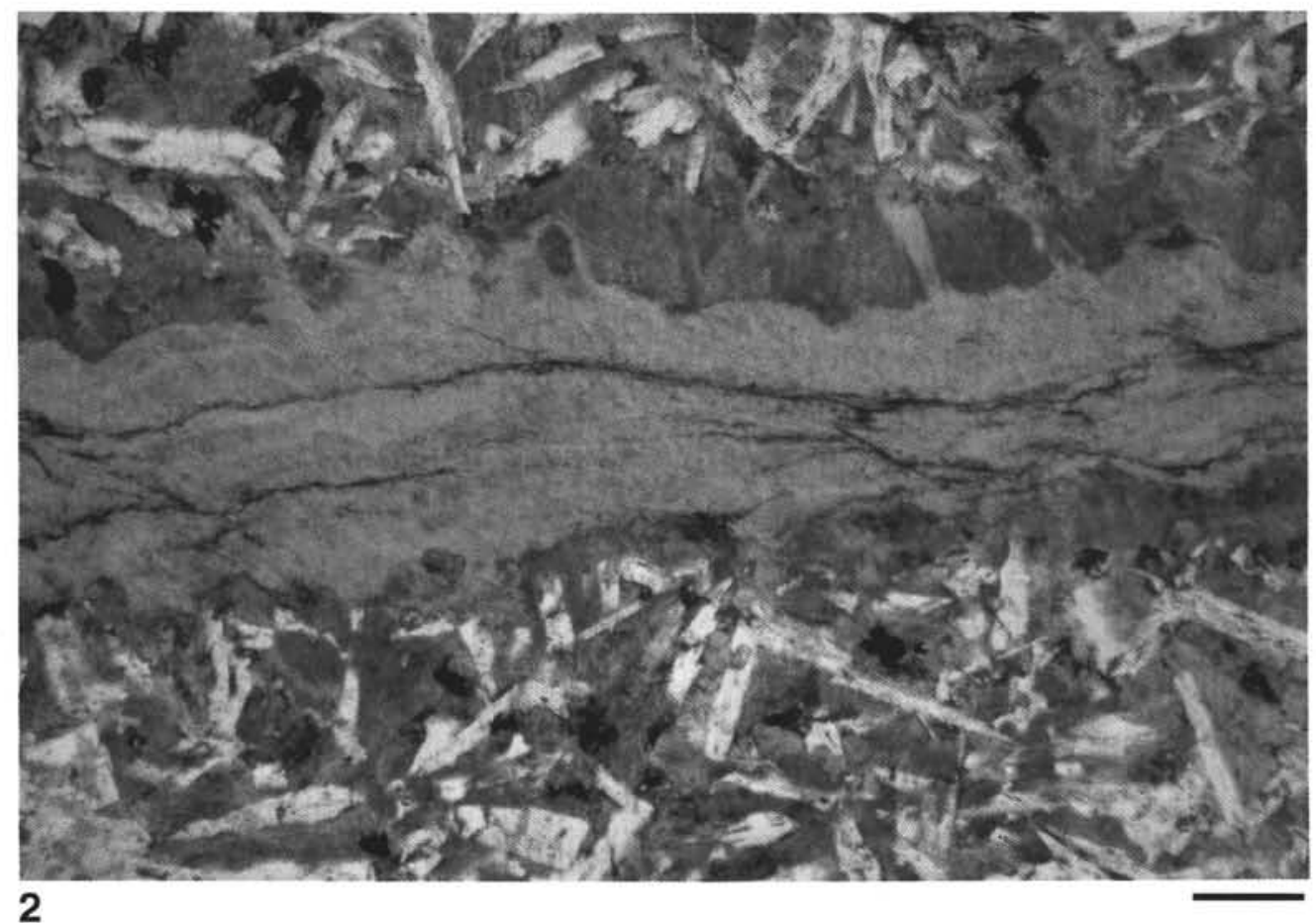

Laverne et al. (1995), Plate 1. 1. Secondary Na-, Ti-diopside (d) replacing igneous augite (a) in contact with an actonolite (ac) + titanite (ti) vein in Sample 137504B-180M-1, 74-78 cm (Piece 7) (plane polarized light). pl = plagioclase. Scale bar is $1.2 \mathrm{~mm}$. 2. Actinolite vein, hornblende in adjacent alteration halo in Sample 140-504B-197R-1, 100-150 cm (Piece 22) (plane polarized light). Scale bar is $0.5 \mathrm{~mm}$. 
The following plate is reprinted from Laverne et al. (1995) in full color.

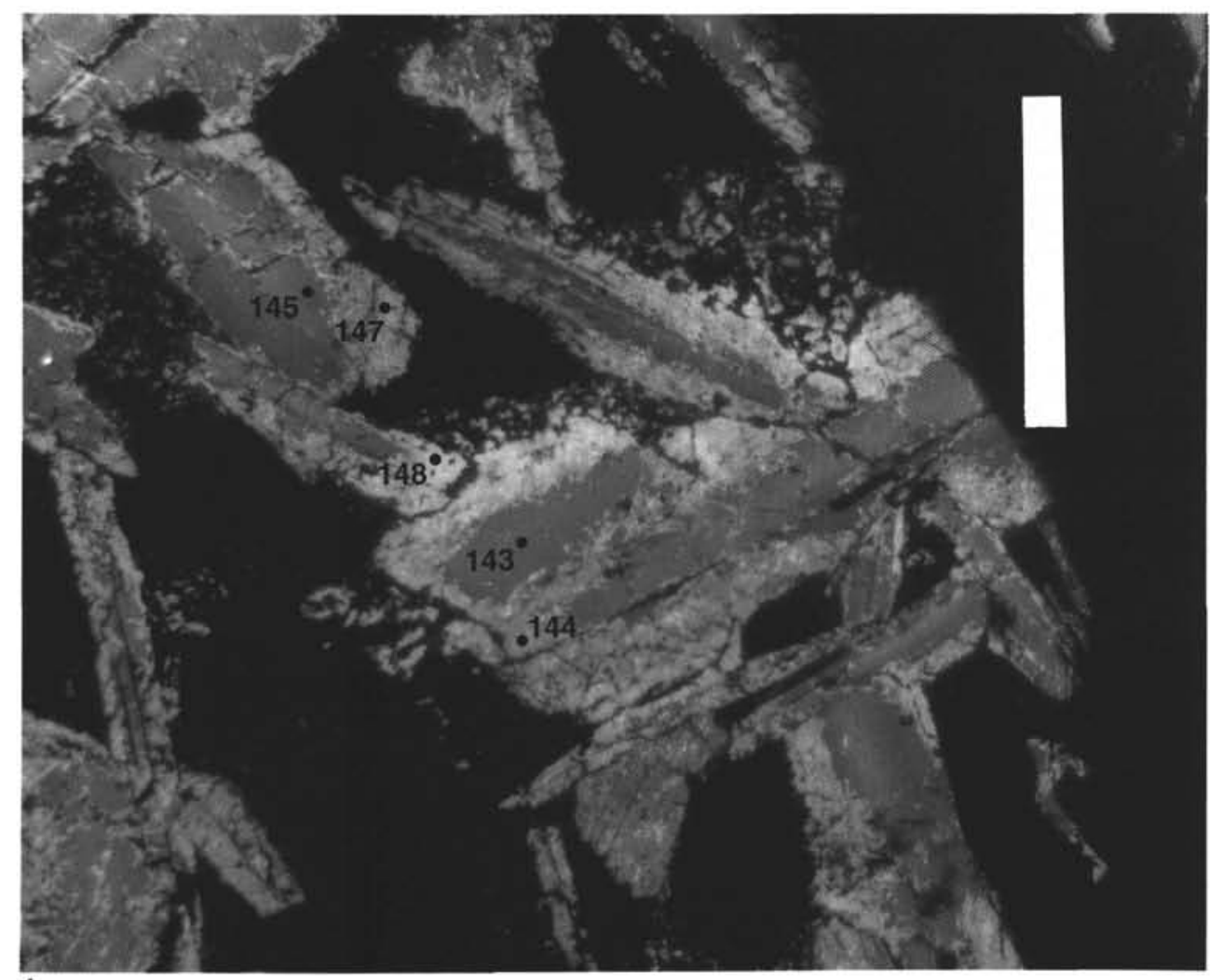

1

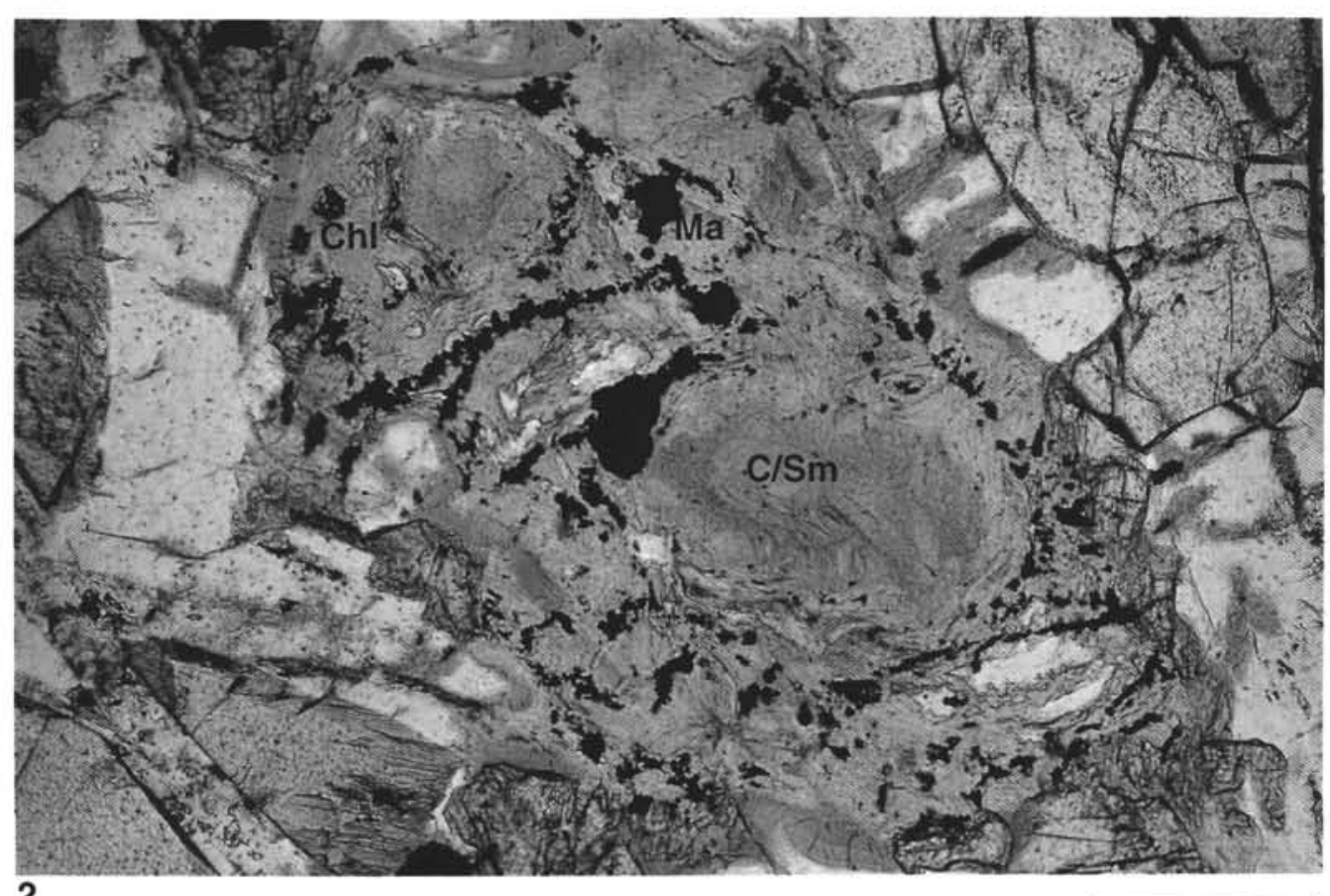

2

Laverne et al. (1995), Plate 2. 1. Photomicrograph of dolerite from a vein halo, Sample 140-504B-205R-1, 13-16 cm (Piece 1), taken with a cathodoluminescence microscope (17 KeV accelerating voltage, $0.5 \mathrm{~mA}$ beam current). The field of view is from a well-developed alteration halo along an amphibole vein. Igneous plagioclase laths luminesce blue-gray and possess thick incomplete rims of greenish hydrothermal calcic plagioclase. Interstitial amphibole is nonluminescent. Electron microprobe analysis spots are labeled. Plagioclase cores are $\mathrm{An}_{74-77}$, whereas the rims are $\mathrm{An}_{89-94}$. Late-stage crosscutting veinlets of nonluminescent albite are $\mathrm{An}_{11}$. Scale bar is $0.5 \mathrm{~mm}$. 2. Olivine phenocryst replaced by chlorite (Chl) + magnetite (Ma) at the rim (analyses B3104, B5009, B5014), mixed layer chlorite-smectite (C/Sm) in the core (analyses B3103, B5025, B5026) in Sample 140-504B-208R-2, 76-81 cm (Piece 13) (plane polarized light). Scale bar is $0.2 \mathrm{~mm}$. 